\title{
Epidemiology and control of human schistosomiasis in Tanzania
}

\author{
Humphrey D Mazigo 1,2,3,4*, Fred Nuwaha², Safari M Kinung'hi ${ }^{3}$, Domenica Morona', Angela Pinot de Moira ${ }^{4}$, \\ Shona Wilson ${ }^{4}$, Jorg Heukelbach ${ }^{5}$ and David W Dunne ${ }^{4}$
}

\begin{abstract}
In Tanzania, the first cases of schistosomiasis were reported in the early 19th century. Since then, various studies have reported prevalences of up to $100 \%$ in some areas. However, for many years, there have been no sustainable control programmes and systematic data from observational and control studies are very limited in the public domain. To cover that gap, the present article reviews the epidemiology, malacology, morbidity, and the milestones the country has made in efforts to control schistosomiasis and discusses future control approaches. The available evidence indicates that, both urinary and intestinal schistosomiasis are still highly endemic in Tanzania and cause significant morbidity.Mass drug administration using praziquantel, currently used as a key intervention measure, has not been successful in decreasing prevalence of infection. There is therefore an urgent need to revise the current approach for the successful control of the disease. Clearly, these need to be integrated control measures.
\end{abstract}

Keywords: Schistosomiasis, S. mansoni, S. Mansoni, epidemiology, morbidity, control, Tanzania

\section{Review Background}

Human schistosomiasis is second only to malaria in subSaharan Africa (SSA) for causing severe morbidities. Of the world's 207 million estimated cases of schistosomiasis, 93\% occur in SSA and the United Republic of Tanzania is the second country that has the highest burden of schistosomiasis in the region, Nigeria being the first [1,2]. Two major schistosome species are prevalent in the region, Schistosoma mansoni and Schistosoma haematobium causing intestinal and urogenital schistosomiasis, respectively $[1,2]$. In Tanzania, numerous surveys have been conducted in the past and more recently to describe the epidemiology, transmission (malacology), clinical trials of anti-schistosomes and control efforts against schistosomiasis (both intestinal and urogenital schistosomiasis), however, this information is very limited in the public domain where they can be easily

\footnotetext{
* Correspondence: humphreymazigo@gmail.com

${ }^{1}$ Department of Medical Parasitology and Entomology, School of Medicine, Catholic University of Health and Allied Sciences, P.O. Box 1464, Mwanza, Tanzania

2Department of Environmental Health and Communicable Disease Control, School of Public Health|, College of Health Sciences, Makerere University, P.O. Box 7072, Kampala, Uganda

Full list of author information is available at the end of the article
}

accessed by public health intervention managers and policy makers. Availability of this information will not only help in implementation of control programs but also will serve to guide control activities in areas with the greatest needs and allocation of resources such as drugs. In attempts to cover that gap, the present article, reviews the epidemiology, transmission dynamics, past and current control approaches and the progress Tanzania has made to control the disease. Clinical features and treatments are discussed. Our review supports the need to reverse the current control approach based on preventive chemotherapy, to an integrated multidisciplinary control approach.

\section{Methods}

Data for this review were identified and collected using manual and electronic search strategies of published and unpublished sources. Electronic databases included PubMed, EMBASE and Global health. References of relevant articles were also screened. Manual identification of unpublished literature sources, including unpublished project surveys, university theses, conference papers and public health organization reports was conducted at The National Institute for Medical Research,

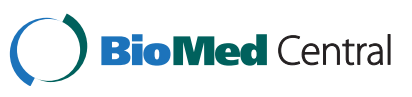


Mwanza, Tanzania. The centre has a library established in the 1940's with archives of information since 1850.

To identify relevant studies on schistosomiasis in Tanzania, the search initially began with the text string "schistosom" and a combination of the following words in permutations were used: "epidemiology", "epidemiology + Tanzania/Tanganyika", "Schistosoma mansoni + Tanzania/Tanganyika", and "Schistosoma haematobium + Unguja + Pemba", "schistosomiasis + Zanzibar", "Biomphalaria/Bulinus + Tanzania/Tanganyika". Available literature was categorized into population-based studies, clinical trials and basic malacology. Inclusion criteria were used with less stringency for the articles or papers that reported co-infections of schistosomiasis and other tropical diseases in Tanzania.

\section{The past and current epidemiology of schistosome infections in Tanzania}

Historical studies have revealed that both Schistosoma haematobium and Schistosoma mansoni have been endemic for a long time in Tanzania. The first scientific report of schistosomiasis in Tanzania can be traced back to 1895 when Manson-Bahr published the first recorded case of intestinal bilharziasis $[3,4]$. The early studies in the Lake Victoria province (Tanzania mainland) by Cook in 1905 at Kwimba identified and described the distribution of S. mansoni and S. haematobium in the region $[3,5]$. Over $50 \%$ of individuals examined had urogenital schistosomiasis [5] and S. mansoni was noted to be widespread on the southern and eastern shores of Lake Victoria [5]. In 1903, urogenital schistosomiasis was noted to be prevalent among men by Petrie in Zanzibar [6,7]. However, it was not until 1925 that urogenital schistosomiasis epidemiology was described $[3,7]$. Other schistosomes species found in the country include Schistosoma bovis, Schistosoma matheei and Schistosoma leiperi which infect bovine species $[8,9]$.

Since the 1920s to date, large and small scale epidemiological surveys have been conducted in the country to determine the distribution [10-12], intermediate hosts [11-13], prevalences and intensity of both urogenital and intestinal schistosomiasis [14-18]. The results revealed that schistosomiasis was highly endemic throughout the country and the level of endemicity varied from region to region. The north-western regions, surrounding Lake Victoria, the northern, central, southern and south east of the country were identified to be highly endemic for $S$. mansoni $[11,13,17]$, while the hinterland areas of the country were highly endemic for $S$. haematobium $[14,15,18]$.

The distribution of S. mansoni and S. haematobium were reviewed by McCullough in 1972 and Doumenge in $1987[3,19]$ and their reports indicated that the distribution of $S$. mansoni was found to be characteristically focal but the main extensive zones were found in the south eastern and south western sides of Lake Victoria and its island [19]. Schistosoma haematobium was widely distributed and two extensive zones where noted to have high transmission, namely the inland on the eastern and south-eastern hinterland of Lake Victoria and lowland zones on the eastern coast of the country [19]. The islands of Unguja and Pemba (Zanzibar islands) were only endemic to Schistosoma haematobium and the geographical distribution of the disease was largely restricted to north-western and central areas of Unguja Island [3,6,7,19-22]. However, Pemba Island, was endemic for S. haematobium on the western, southern, central and northwest of the island [23-27]. Two transmission seasons of the disease were noted in the islands part of the country: the high season, accompanying the long rains which end in between June/July, and low transmission during the dry seasons [28]. It was observed that $S$. mansoni was of little public health importance in the two islands due to absence of its intermediate hosts: snails, the Biomphalaria species $[3,7,19]$.

The construction of the hydroelectric dams and development of irrigations schemes in the late 1970s and early 1980s to meet the needs of the growing population for food production and water supply altered the transmission pattern of schistosomiasis in the country. These water development projects were identified as the risk areas for transmission of schistosomiasis for communities that lived and worked in areas surrounding the hydroelectrical dams and irrigation schemes. The areas created favourable environmental conditions for the snail intermediate hosts and the major impact was that the disease was seen to spread to the areas that were not previously known to be endemic [12,29-35].

Of the national population of 17.5 million people (Tanzania mainland) in 1977, a total of 3.3 million (19\%) people were conservatively estimated to have constant exposure risk to schistosomiasis [36]. According to the estimates in national surveys of 1979-1980, 28.3\% of the population of mainland Tanzania (an approximate of 4.3 million people) and $23.2 \%$ (approximate 3.9 million people) had urogenital and intestinal schistosomaisis, respectively $[36,37]$. The nationwide survey conducted in 1980 among schoolchildren (aged between 9 and 14 years old) showed that more than $50 \%$ had S. haematobium infection, the majority living in the endemic zones of western and eastern parts of the country $[3,36,37]$. In 1990, for the projected population of 23.8 million people, the estimated national prevalence for schistosomiasis was $51.5 \%$ (an approximate of 12.3 million people with schistosomiasis infection) [36].

Today, both urogenital and intestinal schistosomiasis remains as a major public health problem in Tanzania that are endemic at varying transmission levels in all 
administrative regions. Schistosoma haematobium is widely distributed while the endemic areas for S. mansoni are mostly focal $[3,38,39]$. Recently, attempts have been made to map the distribution and risk areas for schistosomiasis transmission using geographical information systems (GIS), remote-sensing (RS) and spatial analysis Figure 1 [40-45]. The observed geographical distribution supports the previous historical mapping on schistosomiasis in the country. Specifically, S. haematobium is highly endemic along the eastern and south-eastern coasts, the islands of Unguja and Pemba (Zanzibar) and the interland areas of the north-western zones of the country [41]. These have been identified as potential areas for the intermediate-host snail species responsible for transmission of S. haematobium [41]. Schistosoma mansoni is absent on the coastal area due to the absence of its intermediate host snails and thermal exclusion $[42,43]$ but is dominant along the shores and islands of Lake Victoria [19].

In the last decade, attempts have been made to estimate the population infected or at risk of contracting schistosomiasis in Tanzania $[38,46]$. In 2000, it was estimated that, of the 29.6 million people in Tanzania, 15.4 million were infected with both urogenital and intestinal schistosomiasis [37]. In 2009, it was estimated that approximately 19 million people are infected with schistosomiasis [47]. The recent report of 2012 indicated that of the estimated population of 43.5 million people, about $23,189,294$ million are infected with schistosomiasis (the country prevalence estimated to be $51.5 \%$ [48]. Because of the wide distribution of schistosomiasis, the entire population of approximately 43.5 million people remains at risk of the disease and the prevalence of the disease appears to increase with increase in population size (from the prevalence of 19\% in 1977 to approximately $51.5 \%$ in 2012).

\section{Malacological survey and disease transmission}

The early malacological surveys to incriminate fresh water snails as intermediate hosts of schistosomiasis started in 1879 in Unguja islands [46,48], where Isidora

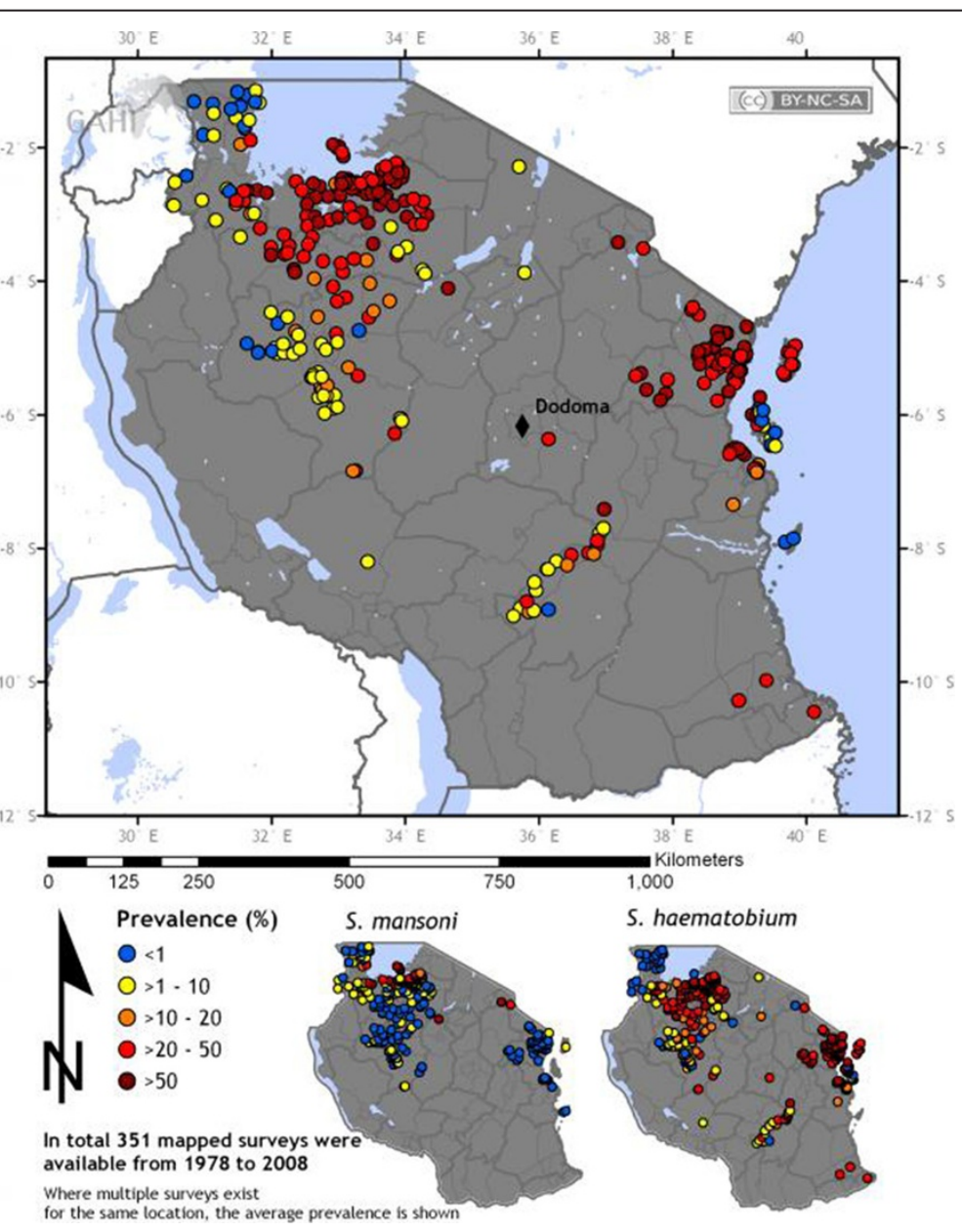

Figure 1 Distribution of schistosomiasis (both S. mansoni and S. haematobium) in Tanzania: Maximum point prevalence of schistosomes infection and location of S. mansoni and S. haematobium surveys in the United Republic of Tanzania. 
(Physopsis) ovoidea was identified as the likely intermediate host of S. haematobium [49,50]. Mozley in 1938 studied the molluscs of the continental part of the country, around the coastal area, the shores of Lake Victoria and the islands and identified Physopsis globosa as the intermediate host of S. haematobium [51].

The earlier reviews of Sturrock [12], McCullough [19] and Brown [51] in the 1970s and 1980s revealed that three Planorbidae were the principal intermediate hosts of S. haematobium, which includedBulinus nasutus, Bulinus globosus and Bulinus africanus. Bulinus nasutusoccurred in the hinterland areas and was commonly observed in a variety of permanent water bodies, which were small and man-made, such as quarry excavations for road construction, rice paddies, swampy pools and temporary water sources throughout the country [3,12,51,52]. Bulinusafricanus and B. globosus were reported to inhabit permanent and larger water bodies both on the hinterland and coastal plain and were commonly seen in temporal streams $[3,12,27,51,52]$.

Molecular data and anatomical classification of the intermediate hosts of schistosomes have helped to resolve the taxonomic identification of important intermediate hosts of schistosomes in Tanzania [52-57]. Through the use of DNA characterization technique, it is now clear that on Unguja island Bulinus globosus is the main intermediate host of Schistosoma haematobium $[53,56,58]$. Although Bulinus nasutushas been identified to exist on the island, it is noteworthy that it is not the intermediate host of $S$. haematobium $[53,56,58]$. These observations indicate that the transmission of S. haematobium in Unguja could only take place within the distribution ranges of B. globosus [53,56,58,59]. On Unguja Island, the distribution of urogenital schistosomiasis corresponds with the distribution of $B$. globosus $[53,56,58,59]$. Bulinus globosushas been commonly observed towards the north of the island [56]. On Pemba Island, both $B$. globosus and B. nasutus are important intermediate hosts of $S$. haematobium, with the latter restricted to the eastern central border of the island but not widely spread [58].

In the mainland part of the country, there are several species of Bulinus and Biomphalaria responsible for transmission of urogenital and intestinal schistosomiasis $[13,54]$. The potential intermediate hosts of $S$. mansoni are Biomphalaria choanomphala, Biomphalaria pfeifferi, Biomphalaria sudanica and Biomphalaria angulosa $[13,19]$. Biomphlaria choanomphala is restricted to the large water bodies such as Lake Victoria and hydroelectrical dams in southern and east-south of the country, whereas $B$. sudanica is commonly observed in dams, in permanent and seasonal water sources around the southern shores of Lake Victoria and on the northern part of the country $[12,13,19,56]$. Biomphlaria pfeifferi has a widespread distribution and occurs throughout the inland (almost $2 / 3$ of the country). The species is commonly observed in seasonal water sources and swamps whereas the $B$. angulosa is commonly seen in swamps in southern highlands $[13,19,52]$. For $S$. haematobium, the main intermediate hosts are Bulinus africanus, B. globosus and $B$. nasutus $[19,60-62]$. On the eastern coastal areas, $B$. globosus is the main snail host responsible for transmission [51]. However, B. africanus is also present in the area but has local importance [51]. By contrast, $B$. nasutus is the major intermediate host in north-western region and is commonly seen in temporary water bodies $[15,19,54]$. The geographical distribution of important snail intermediate hosts and attempted control measures are presented in Table 1.

The distribution and density of the intermediate snail host is an important determinant, accounting to a large extent for seasonal transmission of the disease $[3,12,27,51]$. The absence of members of the susceptible species of the planorbid genus Biomphalaria along the east coast areas and on the two islands of Unguja and Pemba is associated with the apparent absence of $S$. mansoni transmission in these areas [12,19]. Similarly, the distribution of S. haematobium and S. mansoni along Lake Victoria is largely related to the distribution of the intermediate hosts [65]. Along the shore of the lake members of the genus Biomphalaria are common $[13,67]$ with populations living along the lake shores and islands being highly affected by $S$. mansoni as the risk of infection increases $[67,68]$. For S. haematobium, Bulinus species occurs far inland from the lake shores [14-16] and transmission of the infection is very common in the hinterland areas, except for parts of Kagera region where transmission does not occur due to the absence of these intermediate hosts $[13,52,54,61,67]$.

\section{Epidemiology and transmission}

The prevalence, intensity of infection, and transmission intensity of schistosomiasis is determined by numerous factors including socio-economic, human behaviour, ecology and biological factors which influence the interactions between human and animal hosts and life cycle stages of the parasites.

\section{Human water contact behaviours and transmission patterns}

The various permanent and temporal water bodies existing in the country contribute significantly to the ecoepidemiological transmission of schistosomiasis. The inland water bodies on the southern shore of Lake Victoria contribute significantly to the transmission of $S$. haematobium $[13,52,54,61,67]$. Malacological and ecological surveys have identified several of the inland water bodies infested with Bulinus species (B. nasutus, B. africanus and $B$. globosus), which were shedding cercariae $[61,68]$. Large 
Table 1 Malacological studies from different epidemiological settings and attempted control measures in Tanzania

\begin{tabular}{|c|c|c|c|c|}
\hline Genus & $\begin{array}{l}\text { Host snail } \\
\text { species }\end{array}$ & Geographical distributions & $\begin{array}{l}\text { Potential hosts } \\
\text { for }\end{array}$ & Attempted control measures \\
\hline Bulinus & $\begin{array}{l}\text { Bulinus } \\
\text { globosus }\end{array}$ & $\begin{array}{l}\text { Unguja, Pemba, Pemba and all regions } \\
\text { of mainland Tanzania. }\end{array}$ & $\begin{array}{l}\text { Schistosoma } \\
\text { haematobium, - } \\
\text { is not } \\
\text { intermediate } \\
\text { hosts in Unguja }\end{array}$ & $\begin{array}{l}\text { - On-going- Chemical control using } \\
\text { (molluscicides-neclosamide) in Unguja } \\
\text { and Pemba (http://www.score.uga.edu/ } \\
\text { Elimination.html www.controlled-trials. } \\
\text { com/ISRCTN48837681/) }\end{array}$ \\
\hline
\end{tabular}

References

Sturrock., 1965

[12]

McCullough

[19]

Webbe, 1966

[52]

Stothard et al.,

[53]

Lwambo,1988

[54]

Mandahl-Barth

[55]

Stothard et al., [56]

Stothard et al., [58]

Webbe et al., 1958 [61]

Zumstein

1983 [62]

Jordan and

Webbe., 1982

[65]

Stothard et al., [66]

On-going Chemical control using (molluscicides-neclosamide) in Unguja and Pemba (http://www.score.uga.edu/ Elimination.html)
Mwambungu., 1988 [8]

Kinoti., 1964

[9]

Sturrock., 1965

[12]

McCullough

[19]

Webbe, 1966

[52]

Lwambo,1988

[54]

Mandahl-Barth

[55]

Stothard et al., [56]

Jelnes et al.,

[57]

Marti et al.,

1985 [67]

Gabone et al., [68]

$\begin{array}{lll}\begin{array}{l}\text { Bulinus } \\ \text { africanus }\end{array} & \text { Not present in Unguja and Pemba. } & \text { S. haematobium, None } \\ \text { africanus } & \text { part of the country. } & \text { S. bovis, } \\ & & \text { S. matheei, } \\ & \text { S. leiperi }\end{array}$

Doumange et al., 1987 [3]

Mwambungu., 1988 [8]

Kinoti., 1964

[9] 


\begin{tabular}{|c|c|c|c|c|c|}
\hline & & & & & $\begin{array}{l}\text { Mutani et al., } \\
\text { [69] }\end{array}$ \\
\hline & & & & & $\begin{array}{l}\text { Stothard et al., } \\
{[66]}\end{array}$ \\
\hline & Bulinus forskalii & $\begin{array}{l}\text { Probably all regions of mainland part } \\
\text { of the country, no report from Unguja }\end{array}$ & S. bovis & None & $\begin{array}{l}\text { Mwambungu., } \\
1988[8]\end{array}$ \\
\hline & & $\begin{array}{l}\text { and Pemba. Present in the Mafia } \\
\text { islands }\end{array}$ & & & $\begin{array}{l}\text { Kinoti., } 1964 \\
{[9]}\end{array}$ \\
\hline & & & & & $\begin{array}{l}\text { Mutani et al., } \\
{[69]}\end{array}$ \\
\hline Biomphalaria & $\begin{array}{l}\text { Biomphalaria } \\
\text { choanomphala, }\end{array}$ & - Confined in the large water bodies & $\begin{array}{l}\text { Schistosoma } \\
\text { mansoni }\end{array}$ & None & $\begin{array}{l}\text { Magendantz., } \\
1972[13]\end{array}$ \\
\hline & & $\begin{array}{l}\text { - The lake Victoria. Common in the } \\
\text { three regions bordering the lake. }\end{array}$ & & & $\begin{array}{l}\text { McCullough } \\
\text { et al., } 1962 \\
{[19]}\end{array}$ \\
\hline & & $\begin{array}{l}\text { - Absent on the eastern and southern } \\
\text { coastal belt bordering Indian ocean, } \\
\text { Unguja and Pemba. }\end{array}$ & & & $\begin{array}{l}\text { Brown., } 1980 \\
{[51]}\end{array}$ \\
\hline & $\begin{array}{l}\text { Biomphalaria } \\
\text { pfeifferi }\end{array}$ & $\begin{array}{l}\text { - All regions of mainland part of the } \\
\text { country except the eastern coastal } \\
\text { regions, Unguja and Pemba. }\end{array}$ & $\begin{array}{l}\text { Schistosoma } \\
\text { mansoni }\end{array}$ & $\begin{array}{l}\text { - Chemical control (Bayer } 73, \mathrm{~N} \text { - } \\
\text { tritylmorpholine in irrigations scheme } \\
\text { northern Tanzania }[63,70]\end{array}$ & $\begin{array}{l}\text { Utzinger and } \\
\text { Tanner., } 2000 \\
\text { [60] }\end{array}$ \\
\hline & & & & & $\begin{array}{l}\text { Webbe., } \\
1964 \text { [71] }\end{array}$ \\
\hline & & & & - Biological control $[72,73]$ & $\begin{array}{l}\text { Crossland., } \\
1963[70]\end{array}$ \\
\hline & $\begin{array}{l}\text { Biomphalaria } \\
\text { sudanica }\end{array}$ & $\begin{array}{l}\text { All regions of mainland part of the } \\
\text { country except the central regions of }\end{array}$ & $\begin{array}{l}\text { Schistosoma } \\
\text { mansoni }\end{array}$ & - Molluscicides [74] & $\begin{array}{l}\text { Doumange } \\
\text { et al., } 1987 \text { [3] }\end{array}$ \\
\hline & & $\begin{array}{l}\text { southern coastal regions, Unguja and } \\
\text { Pemba. }\end{array}$ & & & $\begin{array}{l}\text { Magendantz., } \\
1972[13]\end{array}$ \\
\hline & & & & & $\begin{array}{l}\text { Sturrock., } \\
1962[12]\end{array}$ \\
\hline & $\begin{array}{l}\text { Biomphalaria } \\
\text { angulosa }\end{array}$ & $\begin{array}{l}\text { Common in lower lands and highlands } \\
\text { southern }\end{array}$ & $\begin{array}{l}\text { Schistosoma } \\
\text { mansoni }\end{array}$ & None & $\begin{array}{l}\text { Magendantz., } \\
1972[13]\end{array}$ \\
\hline & & & & & $\begin{array}{l}\text { Sturrock., } \\
1962[12]\end{array}$ \\
\hline & & & & & $\begin{array}{l}\text { Webbe and } \\
\text { Jordan., } 1966 \\
\text { [52] }\end{array}$ \\
\hline
\end{tabular}

water bodies such as Lake Victoria, hydroelectrical dams and irrigations schemes (paddy and sugarcane irrigation schemes) are inhabited by Biomphalaria species (B. chaonomphala, B.sudanica and B.pfeifferi) [29-34]. The majority of the transmission of schistosomiasis occurs within the large water bodies, dams, irrigation schemes and in seasonal/temporal water bodies, predominantly around Lake Victoria shores and its islands. Dams and irrigation schemes for S. mansoni and the eastern coast belt and the Unguja and Pemba islands are predominant areas for $S$. haematobium [3,19]. To date, studies on human water contact and the influence of socio-economic factors on the transmission of schistosomiasis are very limited in Tanzania. These types of studies from other schistosomiasis endemic countries, using direct observations or interviews/surveys [75-78] have contributed significantly to identifying high risk individuals and groups in areas with focal transmission of the disease [28,75-78]. High water contact is a risk factor and a means of becoming infected for groups involved in fishing, farming, washing in water bodies and swimming [28,75-78]. Among these groups, high water contact behaviour is gender related. Males are reported to have higher water contact behaviour than females [28,75-78]. In addition, high water contact in males has been observed to correspond with a high peak of cercarial shedding [28,75-78]. Age-related water contact behaviour has also been observed. Studies in Africa have reported high water contact in the age group $<21$ years and other studies in age group $>21$ year [28,75-78]. 
In Tanzania, human exposure to schistosomiasis is mostly related to occupational activities such as fishing, farming or recreational activities around the basin or within the permanent or temporal water bodies such as lakes, rivers, dams, swampy areas or road side ditches. There is variation in water contact behaviour from one region to another region due to differences in distance to water bodies, socio-economic conditions and ecological variation [28,75-78] Figure 2.

The transmission pattern of schistosomiasis is seasonal and alternates between rainy and dry seasons $[15,16]$. In areas surrounding the southern shore of Lake Victoria and on Unguja Island, two distinct transmission seasons of $S$. haematobium have been observed [13,16,52]. The first season is observed between February- May and is concurrent with the long rainy seasons $[13,16,52]$. During this season, the number of temporal water bodies in hinterland increases, volume of water in seasonal rivers increases and the female Bulinus species starts to lay a large number of eggs which hatch by the end of long rainy season $[15,16]$. Thus, shortly after the long rainy season, the population density of Bulinus increases and both young and mature snails shed cercariae at high rates $[13,16,52]$. At the start of the dry season, between June and July, the ambient temperature increases and creates a favourable environment for human water contact through swimming and fishing. This exposure to cercariae infested water increases the rate of disease transmission $[13,16,52]$. The second transmission season is observed during the dry season (July - September/ October) characterized by decreased Bulinus population density, drying out of most of the temporal water bodies, decreased water volume in seasonal rivers and no agriculture work in the hinterland areas [13,16,52]. The adult snails die during the dry season and the young snails undergo aestivation under the soil to ensure survival during the next season and species survival adaptation $[13,16,52]$. During this period, the transmission rate is low and sporadic. However, in other areas the transmission pattern is observed shortly after the short dry season [54].
For S. mansoni, in the hinterland areas, the transmission pattern follows that of S. haematobium due to seasonality of water bodies. However, in permanent water bodies, such as around Lake Victoria, irrigation schemes or around hydroelectrical dams, the transmission is different and does not occur in seasons. In these areas, there is continual transmission with slight or no difference between the rainy and dry season $[13,15,16,52]$.

\section{Primate - Human schistosomiasis transmission}

The zoonotic transmission of $S$. mansoni between human and other primates occurs in Tanzania, but this topic has received little attention [79-81]. Monkeys and baboons are known to be infected by $S$. mansoni in their ecological areas [79-81]. Studies involving these primates in their vicinity or protected national parks have reported high incidence of $S$. mansoni in monkeys and baboons. These primates act as reservoirs for the infection to humans and play a major role in the transmission of the disease [79-81]. However, the potential roles played by monkeys/baboons as reservoir hosts of human schistosome infections have never been studied in detail. The movement of baboons from the national parks to human settlements may establish transmission of intestinal schistosomiasis in areas known to be free of the disease, especially if the intermediate hosts are present in that area. Thus, advanced studies are required to understand the roles played by baboons/monkeys in the dynamic transmission of intestinal schistosomiasis.

\section{Population prevalence and intensity of infection}

Like other schistosomiasis endemic countries, in Tanzania the prevalence of schistosomiasis and intensity of infection varies between geographical areas, age groups and gender. Studies have reported high prevalences (40\% to $100 \%$ ) of S. mansoni in populations living along the Lake Victoria shores and within islands, irrigation schemes and around the hydroelectrical dams $[5,17,44,45,82-84]$. For S. haematobium, the high prevalence is observed in hinterland areas located on the southern shore of Lake Victoria, the eastern coastal areas and on Unguja and Pemba islands
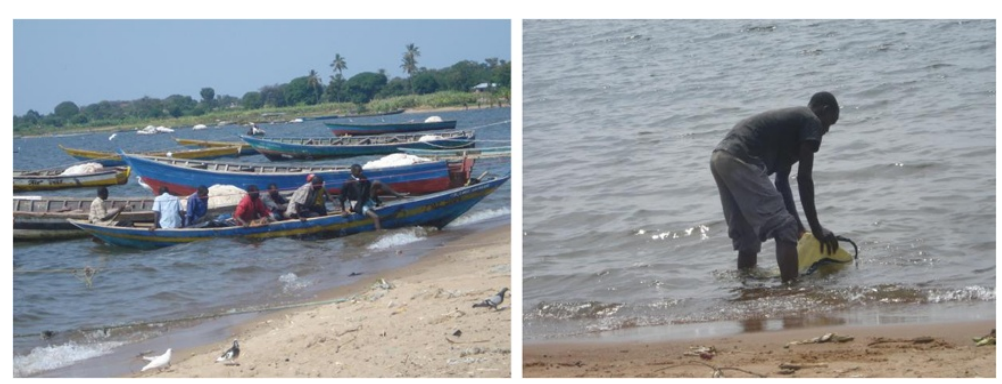

Figure 2 Active water contact activities such as fishing, fetching water direct from the lake and agriculture along the lake basin increases the risk of S. mansoni transmission on the southern shore of the Lake Victoria, north-western Tanzania. 
$[3,10,11,14,15,18,19]$. Prevalence and infection intensity are highest among school children $<15$ years of age $[36,37]$. The age distribution pattern of schistosomiasis has been reported to peak between ages 10-19 years and decrease there after with increased age [36,37]. Similarly, a gender variation in prevalence of S. mansoni appears to have a variation and the variations are attributed to differences in economic activities and exposure to cercariae infested water. Males are exposed more to water during fishing and swimming as compared to females $[36,37,85]$. In terms of age variation in prevalence, community studies have observed individuals aged $<30$ years having higher $S$. mansoni prevalence as compared to those who were $>30$ years [83-85]. Similarly, for S. haematobium infection an age-dependent pattern of infection peaks at the age group of 5-19 years old and a decrease in the $>20$ year-olds [86]. The intensity of infection differs significantly between males and females with mainly young age groups (14-19 years old) diagnosed with heavy infection both for $S$. mansoni and $S$. haematobium $[5,82,83,86]$. Development of immunity against schistosomiasis is attributed to the age pattern observed and the decrease of the prevalence and intensity of infection at older ages.

In communities where occupational exposure is unavoidable for a large proportion of the adult population, for example in fishing and farming communities, adults are more exposed to cercarial infested water than the young generation due to their occupations, such as paddy cultivation in swamps or fishing in lakes $[54,65,86]$. This age difference in prevalence and infection intensity can also be influenced by school based control approaches, in which the control intervention is only centered around school children and the adult population is not included, which has been for example, observed in China and the Philippines $[87,88]$.

\section{Schistosomiasis pathology and patterns of morbidity}

Chronic schistosomiasis (both intestinal and urogenital) results from the host's immune response against the egg antigens (hepatotoxins -Omega-1) which reach the body tissue through the micropores in the egg shells and $[89,90]$. The hepatotoxins provoke an eosinophilic response and type IV (delayed) hypersensitivity reactions mediated through $\mathrm{T}$ helper cell $\left(\mathrm{Th}_{2}\right)$ immune response to antigens $[89,90]$. The immunological reaction produced eventually leads to formation of granuloma, which ends up as a fibrosis formation [89,90]. The resulting pathology depends on several factors such as hostparasite genetics [91], degree and length of exposure [92], intensity of infection [92], host immune response to the parasites and co-infections with other tropical diseases such as malaria and HIV-1 [93,94]. Chronic schistosomiasis associated with immune response against eggs trapped in various body tissues is commonly reported in Tanzania $[4,83,84,86]$.

\section{Chronic urogenital schistosomiasis}

Schistosoma haematobium worms are strategically located at the terminal venules, which tend to enhance passage of the laid eggs to the lumen of the bladder, pelvic organs and rarely in the gastrointestinal organs [95]. The deposited eggs provoke granulomatous inflammation and the primary organ affected is the ureter [89]. The developed lesions lead to the formation of sandy patches, ulcerations and polypoid lesions in the bladder and ureters, resulting in haematuria, obstructions of urine flow, calcified bladder wall and cancer $[14,18,95,96]$. Common early signs include dysuria, proteinuria, and haematuria [95-111]. The development of urological abnormalities related to S. haematobium infection is associated with the intensity of infection [96,112-115]. Several epidemiological and clinical studies conducted in Zanzibar (Unguja and Pemba) and the mainland part of the country have reported high prevalences of $S$. haematobium and different types of morbidities associated with urogenital schistosomiasis across all age groups and gender (Table 2). The common urogram abnormalities were calcified urinary bladder, calcified and distorted ureters, hydronephrosis and nonfunctioning kidney [96,112-116]. In addition, multiple or bilateral lesions were also identified, including calcified bladder, deformity of the ureter, hydronephrosis and non-functioning kidneys [112-116]. A direct relationship between intensity of infection and the abnormalities of the urinary tract was observed, in which calcified urinary bladders, deformed ureters and hydronephrosis were significantly more common in schoolchildren who had higher infection intensities (excreted $>250$ eggs $/ 10 \mathrm{ml}$ of urine) [112-115]. Similar findings were reported in Unguja and the observed urological complications were associated with high intensity of infection [112-115]. Ultrasonographical surveys in the south east of the country, the areas endemic for S. haematobium, produced similar results, but the overall rate of urological abnormalities was high [96]. Recently, factors such as pain on micturating, urgency, loin pain, tired by midday, self-reported frothy urine, self-perceived haematuria, self-reported schistosomaisis in past year, detected haematuria and presence of S. haematobium eggs in urine were major risk factors for urinary tract abnormalities detected by ultrasound [116]. Details of the results of other studies on morbidities associated with urogenital schistosomiasis are presented in Table 2.

In Tanzania, genital schistosomiasis due to eggs of $S$. haematobium trapped especially in the female reproductive tract is a public health concern [120,123-125]. 
Table 2 Epidemiological and clinical studies reporting prevalence, intensity of infection and morbidities associated with schistosomiasis in Tanzania

\begin{tabular}{llll}
\hline Articles & Parasites & Major findings & Geographical area \\
\hline Jordan, 1961 & S. haematobium and & A total of 203 individuals were examined. Higher incidence of & Usagara, Sukuma- \\
[14] & S. mansoni & S. haematobium in the age group 6-12 year olds (78\%) and & land, north-western \\
& & $50 \%$ in the > 12 years of age. Only 12 individuals had & Tanzania
\end{tabular}

Forsyth and Bradley, 1966 [113]

S. haematobium and S. haematobium

Forsyth and

S. haematobium

MacDonald

1965 [112]

$\begin{array}{ll}\text { McMahon } 1967 & \text { S. mansoni and } \\ {[82]} & \text { S. haematobium }\end{array}$

Forsyth, 1969 S. haematobium [114]

Rugemalila., 1981 S. haematobium [18]
A total of 2,338 people (1580 males, 758 females) were studied. Overall prevalence was $42 \%$ ( $42 \%$ vs $41 \%$ between males and females) and the age group 6-17 years having a prevalence of $69 \%$. The prevalence of S. mansoni was $24 \%$ with the majority having light infection and showing a sex difference in prevalence, being common in men (31\% versus 15\%). Schistosoma mansoni infection was common in individuals living in villages close to the lake and S. haematobium was higher in villages located in the hinterland.

- Prevalence of splenomegaly (Hackett grade 2 or more) was $25 \%$ and $8 \%$ for individuals identified to have S. mansoni infections.

- Splenomegaly and hepatomegaly was also seen in individuals who had no S. mansoni infections and was presumed to be caused by malaria infection.

Three urine samples collected from each of the 517 school children. The overall prevalence of S. haematobium was $45.3 \%$ (234/217) and sex difference in prevalence was observed with boys having a prevalence of $51 \%$ versus $37 \%$ in girls. Infected children were observed to excrete up to more than 4000 eggs/ $10 \mathrm{mls}$ of urine. The prevalence of $\mathrm{S}$. haematobium was observed to vary with villages divided as "good and bad villages". In terms of pathological lesions, $43.4 \%$ had different urological lesions (calcified bladder, deformed ureters, hydronephrosis) from "bad villages" and 17.4\% from "good" villages.

640 individuals examined and 200 went through a thorough clinical examination. The prevalence of S. mansoni was $65.2 \%$, $12.2 \%$ for S. haematobium and $3.4 \%$ had mixed infections (S. mansoni and S. haematobium). On clinical examination, 57\% and $19.3 \%$ of individuals of different age groups infected with S. mansoni had palpable splenomegaly and hepatomegaly. Similarly, $29.4 \%$ and $12.8 \%$ of the individuals infected with only S. haematobium had palpable spleens and liver. Other parasitic infections such as malaria contributed to hepatomegaly and splenomegaly.

A two year longitudinal study which studied 1004 people. Overal prevalence of S. haematobium was $65.1 \%$ and the prevalence was higher in the age group between 7 and 17 years (90\% - 100\%). The prevalence of urological abnormalities (based on urograms results) was $35.4 \%$.

- The infection intensities (number of eggs excreted) were reported to exceed 2000 eggs $/ 10 \mathrm{mls}$ of midday urine.

- Haematuria was common in young children and less in older and adult individuals. The urograms of 201 (45.8\%) males and 80 (22.5\%) were abnormal. The overall prevalence of pathological lesions was $35.4 \%$ [calcified bladder 14\%, deformed ureters $23.8 \%$, hydronephrosis $15 \%$, non-functioning kidney $4.5 \%$ and stones $0.5 \%]$. These pathological lesions were more common in males than in females and were observed to increase with age.

900 individuals examined from two communities, prevalences of S. haematobium ranged from $54 \%$ to $57 \%$ with peaks of $66 \%-67 \%$ among the 5-9 years olds. Almost $90 \%$ of the infected individuals had symptomatic vesical lesions and radiological examination of 100 individuals selected randomly revealed that $28 \%$ had bilateral uretero-renal lesions.

3,478 school children examined for S. haematobium. The overall prevalence of $S$. haematobium infection among the school children
Bukumbi chiefdom, north-western

Tanzania.

Unguja (Zanzibar)

Mwanza and Ukerewe, northwestern Tanzania.

Unguja (Zanzibar)

Mwanza, northwestern Tanzania.

Ifakara, SouthEastern Tanzania. 
Table 2 Epidemiological and clinical studies reporting prevalence, intensity of infection and morbidities associated with schistosomiasis in Tanzania (Continued)

\begin{tabular}{|c|c|c|}
\hline & & $\begin{array}{l}\text { (6-19 years) was } 21 \% \text {. The highest prevalence was observed in both } \\
\text { sexes in the age group } 15-19 \text { years. Distinct variations in prevalence } \\
\text { were found between the individual schools examined, ranging from } 5 \\
\text { to } 71 \% \text { and indicating a focal transmission of the disease. The intensity of } \\
\text { S. haematobium infection in the individual schools was relatively low, } \\
\text { ranging from } 5 \text { to } 36 \text { eggs/10 } \mathrm{ml} \text { urine. However, the frequency of } \\
\text { microhaematuria among infected subjects was high, reaching } 100 \% \\
\text { from an egg output of } 50 \text { eggs/10 ml onwards. Forty-nine water-bodies, } \\
\text { most of them man-made-with Bulinus (Ph.) globosus and/or B. (Ph.) } \\
\text { nasutus were identified. }\end{array}$ \\
\hline $\begin{array}{l}\text { Sarda et al., } 1985 \\
\text { [99] }\end{array}$ & S. haematobium & $\begin{array}{l}2,500 \text { school children from } 12 \text { primary schools. The prevalence in the } \\
\text { schools ranged from } 5.3 \text { to } 55.1 \% \text {, with an overall prevalence of } 19.3 \% \text {. } \\
\text { More males ( } 23.5 \% \text { ) than females (15.0\%) were infected, and the highest } \\
\text { prevalence was recorded in the } 11-16 \text { year old age group. Intensity of } \\
\text { infection was higher, ranging from } 12 \text { to } 96 \text { eggs } / 10 \mathrm{ml} \text { urine in individual } \\
\text { schools. } 26 \% \text { of the infected excreted more than } 50 \text { eggs } / 10 \mathrm{ml} \text { urine } \\
\text { and high rates of haematuria and proteinuria were observed in infected } \\
\text { children. Malacological surveys showed two potential vectors, Bulinus } \\
\text { globosus and B. nasutus. }\end{array}$ \\
\hline $\begin{array}{l}\text { Kitinya et al., } \\
1986[117]\end{array}$ & S. haematobium & $\begin{array}{l}\text { Histopathological examination of } 172 \text { cases of urinary bladder cancer, } \\
72 \% \text { had squamous cell carcinomas and } 46 \% \text { had S. haematobium eggs. }\end{array}$ \\
\hline $\begin{array}{l}\text { Savioli et al., } \\
1990[25] .\end{array}$ & & $\begin{array}{l}520 \text { individuals examined for visual haematuria and parasitological } \\
\text { examination. Strong variability of day to day of egg excretion within the } \\
\text { study participants was observed both in the whole population and the } \\
\text { age group } 5-19 \text { years. The prevalence of participants excreting one or } \geq \\
50 \text { eggs } / 10 \mathrm{ml} \text { of urine ranged between } 36 \%-61 \% \text {. Gross haematuria had } \\
\text { higher specificity ( } 100 \% \text { ) in relation to positive filtration on any day of } \\
\text { examination and egg counts of } \geq 50 \text { eggs } / 10 \mathrm{mls} \text { of urine. Also a positive } \\
\text { reaction of haematuria of any day of examination was associated with the } \\
\text { study participants having a high egg count ( } \geq 50 \text { eggs/10ml urine). }\end{array}$ \\
\hline
\end{tabular}

Savioli et al. S. haematobium

1989 [26]

Mgeni et al., 1990 [101]

\begin{tabular}{|c|c|}
\hline $\begin{array}{l}\text { Albonico et al., } \\
1997 \text { [107] }\end{array}$ & S. haematobium \\
\hline $\begin{array}{l}\text { Kardorff et al., } \\
1997 \text { [83] }\end{array}$ & S. mansoni \\
\hline
\end{tabular}

879 individuals examined for S. haematobium and 520 had six days complete urine samples examination. Overall prevalence based on urine filtration technique was $26-34 \%$ and in the age group 5-19 years and the highest prevalence of heavy infection was in the age group 10-14 years. The prevalence of haematuria detected by the reagent strips was similar to prevalence of infection as measured by the highest egg counts. Thus, urine reagent strips are useful diagnostic indicators of $S$. haematobium.

4,113 individuals examined at least once during two years period. First survey, 2,685 individuals examined, $49.3 \%$ had S. haematobium infections and $19.3 \%$ with heavy infection. The age group 10-14 years had higher prevalence of heavy infection (30.2\%). Second survey, 1887 examined, $39.8 \%$ had infection and $13.5 \%$ with heavy infection. The age group 5-9 years old, $27.2 \%$ had heavy infection. Third survey, 2,458 individuals were examined, $34.5 \%$ had infection and $10.9 \%$ were heavily infected. Fourth survey, 1719 individuals were examined, 23.2\% had infection and 7.3\% were heavily infected. S. haematobium is highly endemic in the areas and the age group 5-14 years had highest prevalence and heavily infected.

3,605 school children examined for S. haematobium and other parasitic infections, 31\% of the children had detectable haematuria and about $67 \%$ of them had co-infections of S. haematobium and geohelminths.

Parasitological and ultrasonographical examination of 1,659 and 898 individuals for S. mansoni. High prevalence and intensity of infection in all the three villages was observed, with children and adolescents more infected than adults, and males excreting more eggs than females. Overall prevalence of S. mansoni infection was $86.3 \%$ and mean egg output was 514 epg (geometrical mean egg output was $161.1 \mathrm{epg}$ ). Prevalence of hepatomegaly (detected by ultrasonography) was 35\% and $80 \%$ had splenomegaly. Organomegaly was strongly associated with heavy epg. For periportal fibrosis, 29.8\% had grade I, 5.1\% had grade II, 1.1\% had grade III and fibrosis was observed to increase with age. Late stage disease with a high degree of periportal fibrosis, shrinking of the right lobe of the liver and features of portal hypertension was seen in $2.1 \%$ of the individuals. The overall level of schistosomal morbidity was classified as intermediate.
Dar Es Salaam,

Eastern Coast,

Tanzania

Northern Tanzania

Pemba

Pemba Island

Zanzibar

Pemba Islands

Ukerewe, northwestern Tanzania. 


\section{Table 2 Epidemiological and clinical studies reporting prevalence, intensity of infection and morbidities associated} with schistosomiasis in Tanzania (Continued)

Hatz et al., S. haematobium 1998 [96]

Lwambo et al., 1999 [110]

Ndyomugyenyi and Minjas 2001 [97].

Stothard et al., S. haematobium 2002 [106]

Poggensee et al., 2005 [109]

S. haematobium and
S. mansoni

Rollinson et al., S. haematobium 2005 [108]

Ajanga et al. S. mansoni 2006 [118].

Rudge et al., 2008 [59].

Malenganisho S. mansoni et al. 2008 [119].
533 school children examined for urinary tract pathologies. Baseline data collection found urinary tract pathology in $67 \%$ of 533 children. Lesions of the bladder were significantly associated with egg positivity and microhematuria. The attributable fraction estimate of major bladder lesions due to S. haematobium was $75 \%$. In a cohort study, 224 infected children were examined by ultrasound and then treated with a standard dose of $40 \mathrm{mg}$ of praziquantel $/ \mathrm{kg}$ of body weight. They were re-examined at two, four, six, 12, 18, and 24 months after treatment. Before treatment, $76 \%$ had pathologic lesions of the urinary tract. The proportion showing lesions decreased sharply during the first months after treatment to $11 \%$ at six months. At 24 months, lesions were detected in 57\%, and 11\% had developed new severe pathology. In 18 cases, pathology was present throughout, and 34 did not show any pathology throughout the study.

6,897 school children aged 7-20 years. Parasitological examination of S. haematobium and S. mansoni. Prevalence of S. haematobium was 56.5\%, S. mansoni $10.9 \%$ (overall schistosomiasis infection was $63.4 \%$ ) and mixed infection at 4\% (S. haematobium and S. mansoni). Schistosoma haematobium infections was observed to increase with age.

1,200 schoolchildren examined. The overall prevalence, based on microscopic examination of a single urine sample/subject, was $47.6 \%$ Compared with the girls, the boys were more likely to be excreting schistosome eggs $(54.6 \%$ versus $40.8 \% ; P=0.004)$ and they had higher intensities of infection (54 versus $38 \mathrm{eggs} / 10 \mathrm{ml}$ urine; $P=0.001$ ). The children aged 10-14 years had higher prevalences and intensities of infection than those in the younger or older age-group studied.

400 school children from ten different primary schools were examined for S. haematobium; the overall prevalence was $12 \%$ with five schools recording no infection. Primary schools on the west of $39^{\circ}$ degrees $19^{\prime} \mathrm{E}$ and north of $6^{\circ} 10^{\prime} S$ harboured nearly all the infections, with highest prevalence $(55 \%)$ recorded in an area with a high number of B. globosus habitats. The knowledge of schistosomiasis was poor and individuals selfdiagnosis was poor (sensitivity, 8.5\%). Freshwater-contact patterns of schoolchildren differed significantly between schools and correlated well with prevalence of infections within schools.

634 school children examined in two villages, prevalence of $S$. haematobium was $37 \%$ and $86.3 \%$ respectively. For S. mansoni, prevalence was $22.9 \%$ and $43.5 \%$ among the school children. Six years after the intervention, the prevalence of S. haematobium remained almost constant, at 33.5\% and $70 \%$ in the two villages. The prevalence of heavy infection $(\geq 50$ eggs $/ 10 \mathrm{ml}$ urine) decreased from $53.8 \%$ to $34.4 \%$.

305 schoolchildren examined. Prevalence of S. haematobium based on parasitological examination was 53.9\%. Negative association between haemoglobin level and S. haematobium infection intensity was observed. An association between reported pain during micturitions and elevated urine-albumin levels was observed.

972 pregnant women examined. Overall, 63.5\% were infected with S. mansoni with prevalence being highest among younger women and decreased with increased age. Overall, $66.4 \%$ of the women were anaemic and the increased risk of anaemia was associated with heavy ( $\geq 400 \mathrm{epg}$ ) infection of S. mansoni.

150 school children examined for S. haematobium and a questionnaire to assess water contact pattern. Overall prevalence of $\mathrm{S}$. haematobium was $50.6 \%$ with more boys frequently and more heavily infected than girls. In addition, the mean exposure scores was significantly higher in boys than girls. Water contact activities and proximity of children's home to a site harbouring S. haematobium-infected B. globosus were associated with S. haematobium infection.

Parasitological and ultrasonographic examination of 1,447 individuals from two communities (aged 14-87 years). The prevalence of S. mansoni was $78 \%$ and $38 \%$. The geometrical mean egg output was $156 \mathrm{epg}$ and $47 \mathrm{epg}$ for the two communities respectively. The prevalence of periportal fibrosis was $41.5 \%$ and $16.7 \%$ and was associated with high prevalence and intensity of S. mansoni. Periportal fibrosis, increased segmental branch wall thickness and dilated portal vein diameter were more common in males than females.
Ifakara district, southeastern Tanzania

Magu district, north-western Tanzania.

Dar Es Salaam, East Coast, Tanzania

Unguja (Zanzibar)

Mwanga district, northern Tanzania

Unguja (Zanzibar)

Ukerewe, northwestern Tanzania

Unguja (Zanzibar)

Ukerewe and llemela district, north-western Tanzania. 


\section{Table 2 Epidemiological and clinical studies reporting prevalence, intensity of infection and morbidities associated} with schistosomiasis in Tanzania (Continued)

Lyons et al., S. haematobium

2009 [116]

Sousa-

Figueiredo

et al., 2009

[104]

Stothard et al., S. haematobium

2009 [105]

Massa et al.,

2009 [111].

S. haematobium and

S. mansoni

Poggensee

et al., 2000

[120]

Downs et al. 2011 [121]

Scheich et al. 2012 [122]

Stothard

et al., 2012

[66]

S. haematobium S. mansoni
160 from north (highly endemic) and south (low endemic) of the individuals screened for S. haematobium and ultrasonographical examination of urinary tract morbidities. Individuals from endemic areas had higher urinary tract morbidities as compared to individuals from a low endemic area. Having two out of urgency urination, self reporting of previous infections and detection of eggs in urine were good proxy predictors of urinary tract morbidities as detected by ultrasound.

147 school children and 47 adult men examined for S. haematobium prevalence and urinary tract pathologies. The prevalence of egg-patent urinary schistosomiasis was $36.4 \%$ and $46.8 \%$ and that of urinary tract pathologies was $39.4 \%$ and $64.4 \%$ respectively. In school-children, raised urine-albumin concentration (>40 mg/L) was not associated with the prevalence of $S$. haematobium but was strongly associated with the prevalence of micro-haematuria $(76.7, P<0.0001)$. In adults, elevated urine-albumin excretion was associated with urinary tract pathologies, particularly lesions of the bladder was $(\mathrm{OR}=8.4, P=0.013)$. Albuminuria was a good indicator of detecting lower urinary tract pathologies (bladder wall lesions).

66 children examined for urogenital schistosomiasis and urinary tract pathologies. Prevalence of egg-patent schistosomiasis was $65.2 \%$, while $77.3 \%$ had micro-haematuria and $66.1 \%$ had at least one ultrasound-identified urinary tract pathology.

585 children from the community and 555 children from school were examined for S. haematobium, S. mansoni and geohelminths. The prevalence of S. mansoni was $29.4 \%$ for children from the community and $26.8 \%$ for school children. For S. haematobium was $27.6 \%$ and $25.2 \%$ respectively.

657 women examined for S. haematobium and the prevalence was 36\% and median intensity of infection was $2.1 \mathrm{eggs} / 10 \mathrm{ml}$ of urine. The proportion of schistosomiasis of the lower urinary tract on gynecological examination among 359 women was $37 \%$ and the proportion of their urinary schistosomiasis was $42 \%$. Among the 134 women with Female Genital schistosomiasis, 56\% had detectable eggs in urine. Cervical lesion occurred in $75 \%$ of the women with female genital schistosomiasis.

S. haematobium and 457 women aged 18-50 years were examined for female urogenital schistosomiasis. The prevalence of female genital schistosomiasis was $5 \%$ (ranged from $0 \%-11 \%$ ) and female urogenital schistosomiasis was associated with HIV infection and younger age. Overall HIV prevalence was $5.9 \%$ but was $17 \%$ among women with female urogenital schistosomiasis. A significant geographical clustering of schistosomiasis was observed: northern villages near Lake Victoria had more S. mansoni infections, and southern villages further from the lake had more S. haematobium.

360 schoolchildren (aged 6-17 years) were parasitologically and ultrasonographically examined, $62 \%$ and $57.7 \%$ of males and female were infected with $S$. mansoni respectively. The infection intensity ranged from $1-2,440$ epg with $32 \%$ having low grade, $53.2 \%$ having moderate and $14.8 \%$ having heavy infection intensities. On ultrasonographical examination, $90.7 \%$ had splenomegaly, $89.3 \%$ and $30.9 \%$ had right and left lobe hepatomegaly. Only $5.4 \%$ of the children had overt signs of portal fibrosis and $28.5 \%$ had portal vein dilatation. No association was observed between portal fibrosis and infection intensities.

238 children from nine primary schools were examined for S. haematobium. The prevalence of micro-haematuria and egg-patent infection was $18.1 \%$ and $4.2 \%$ respectively. Females had higher prevalence of micro-haematuria compared to males. All egg-patent infections were of light-intensity $(<10$ eggs/10ml). No clear associations between infection prevalence and local water-contact, by school, were found and all 10 of the egg-positive children had a travel history to the nearby mainland or Zanzibar. Retrospective hospital data revealed a low proportion $(<2 \%)$ of egg-patent infections for 20,306 samples tested between the 2000-2005. Malacological survey revealed that four Bulinus species were common in the area (Bulinus nasutus, B. forskalii, B. barthi). No collected snail was observed to shed schistosome cercariae.
Unguja

Unguja

Umba division, Lushoto district, Tanga. Northern Tanzania.

Mwanga district, Kilimanjaro region, Northern Tanzania.

Sengerema and Misungwi districts, north-western Tanzania

Ukerewe district, north-western Tanzania.

Mafia district, Coastal region, Tanzania. 
Symptoms such as bleeding disorders, ulcers, lower abdominal pain and infertility are common among infected women [120,123-125]. Gynecological and pathological findings are mainly confined to the cervix, where common findings include so-called sandy patches, oedema, erosions/ulcerations, and polyps [120,123-125]. In addition, co-occurrence of genital S. haematobium infections and carcinoma of the uterine cervix or carcinomas of the urinary bladder or prostate gland have been reported Figure $3[117,125,126]$. The association between S. haematobium infection and squamous-cell carcinoma of the bladder has been the subject of debate for a long time. Co-existence of squamous-cell or adenocarcinoma of the urinary bladder, prostate gland and eggs of $S$. haematobium has been observed in hospitalized cases $[117,125,126]$. Evidence from other studies indicates an association between $S$. haematobium infections and some types of bladder cancers [95]. In addition, $S$. haematobium associated lesions in the reproductive tract of women may facilitate the transmission of other sexual diseases including HIV (Table 2) [121,127].

\section{Chronic intestinal schistosomiasis}

The predilection sites of $S$. mansoni are the mesenteric veins. Eggs from the fertilized adult female worm tend to transverse the large bowel walls, causing mild to severe gut pathologies $[128,129]$. In mild infections, the symptoms include diarrhea, abdominal pain, bloody stool, nausea, fatigue and drowsiness [83,129]. Eggs which do not manage to pass through the intestinal mucosa to reach the lumen are trapped in the mucosa or other parts, and are swept by the portal blood flow. Because the eggs are too large to pass through the sinusoidal plexus, they accumulate in the presinusoidal venules within the portal triads [128,129]. Immunological response against the

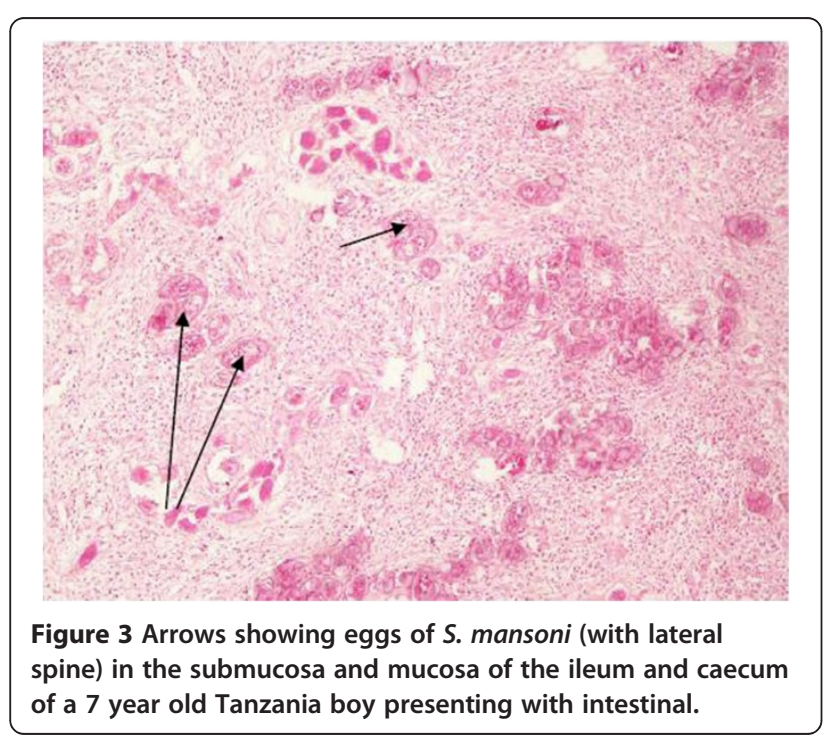

accumulated eggs results in extensive fibrosis of the liver, which may lead to hepatomegaly or splenomegaly/hepatosplenomegaly, venous obstructions, portal hypertension and development of oesophageal varices [128-130]. The rupture of collateral veins in oesophageal varices results in haematemesis [129].

Detailed liver pathology, liver function and haematological findings associated with S. mansoni identified and reported by various epidemiological and clinical surveys are presented in Table $2[17,82-84,119,122]$. In clinical studies common symptoms reported include vague abdominal pain, general weakness, diarrhea, intermittent dysentery and blood/mucus in stool $[82,83,119]$. Ultrasonographical examination has revealed high prevalences of hepatomegaly and hepatomegaly, splenomegaly, hepato-splenomegaly and portal fibrosis. A consistent increase in the proportion of hepatomegaly and splenomegaly with increasing egg output has been observed. Individuals with heavy infections had higher prevalence of both hepatomegaly and splenomegaly $[83,84,119,122]$. Similarly, histological findings have demonstrated extensive fibrosis and granulomatous lesions in liver sections of individuals who had heavy infection intensity $(\geq 500$ epg) [82]. In addition, portal tract fibrosis was severe in liver sections with $\geq 250$ eggs of $S$. mansoni per gram of faeces [82].

In pregnancy, $S$. mansoni is not only the cause of hepatosplenomegaly and other morbidities, but has also been associated with anaemia [118]. Heavy S. mansoni infection ( $\geq 400 \mathrm{epg}$ ) was associated with anaemia [118]. In hospital reports, S. mansoni is the causal factor of appendicitis and intestinal obstructions Figure 4 [131].

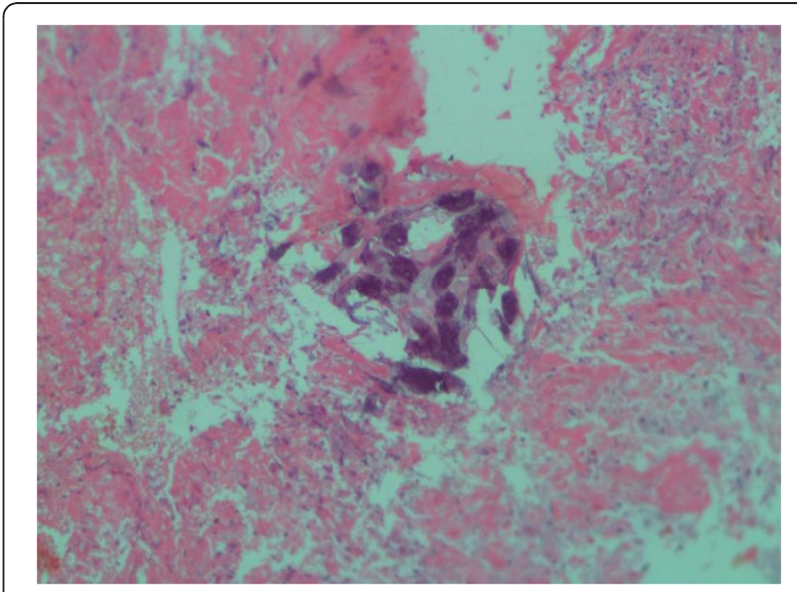

Figure 4 Arrows showing eggs of S. haematobium in the urinary bladder wall of a 40 year old male reported at the Bugando Medical Center, north-western Tanzania with a chief complaint of genital mass and frequent micturitions.

Histological ( $H$ \&E) examination of urinary bladder biopsy revealed co-infections of urinary bladder cancer and S. haematobium eggs in the wall of the bladder and fibrosis. 


\section{Growth retardation and defects in cognitive function}

Schistosomiasis infections during childhood have been associated with growth retardation, anaemia and poor cognitive functions [132-134]. Studies have shown that light to severe infections of either S. mansoni or S. haematobium are associated with stunted growth and undernutrition in infected children [132-135]. In Tanzania, heavy infections of either S. mansoni or S. haematobium were associated with reduced height and weight in infected schoolchildren, in comparison to an uninfected control group [132,133]. Importantly, heavy infection with S. haematobium was associated with impaired mental performance or poor cognitive function in Tanzanian school children $[134,136]$. Evidence from randomized intervention studies indicates that successful chemotherapy results in successful but incomplete catch-up of growth, cognitive function and haemoglobin levels [137].

\section{Co-infection of schistosomiasis with other tropical diseases}

In Tanzania, co-infection of schistosomiasis with other infectious and parasitic diseases such as malaria, geohelminths and HIV are common [107,110,121,138-141]. In primary school children, double or triple infections of schistosomiasis with either malaria or Soil-Transmitted Helminth infections are common $[110,138]$. In this age group, malaria and hookworm infections cause and influence schistosomiasis-related morbidities such as hepatosplenomegaly and anaemia $[138,142]$. Schistosomiasis is reported to influence the severity of malaria infection in school children [143,144]. Co-occurrence of $S$. haematobium/S. mansoni and HIV-1 infections among rural populations has been noted in Tanzania [121], and urogenital schistosomiasis was associated with HIV infection [121]. Emerging putative evidence suggests that there are interactions of schistosomiasis and HIV-1 infections in Africa, with schistosomaisis reported to increase susceptibility to HIV transmission and speed up the progression of HIV/AIDS in Africa [145,146]. The same holds for associations between hepatitis B virus (HBV) and hepatitis C virus (HCV) and S. mansoni infection [147]. As noted in previous studies, there is evidence that co-infections of $\mathrm{HBV}$ and $\mathrm{HCV}$ and $S$. mansoni are associated with deterioration of hepatic function [147].

\section{Past and current control of schistosomiasis in Tanzania}

From the mid-1950s to 1970s, comprehensive control measures were carried out with an emphasis on the control of the intermediate hosts. Various field trials were conducted in the country, using molluscicides to control intermediate snail hosts of $S$. haematobium and $S$. mansoni species (Table 1) [63,70-74,85,148-151]. The common molluscicides studied and used in control of intermediate snail hosts were N-tritylmorpholine, niclosamide ethanolamine salt, sodium pentachlorophenate and Bayer 73 (2-hydroxy-5, 2-dichloro-4-nitro-benzanilide) [63,70-74,85,148-151]. After several field trials of molluscicides, control programmes started and focused mainly in irrigation schemes and the control approach significantly reduced the incidence of $S$. mansoni [63,70-74,85,148-152]. However, the wide distribution of the intermediate snail host of schistosomiasis and their habitats in the country did not allow large-scale country coverage. In addition, molluscicides were expensive and required substantial human and material resources for efficient application [151]. In addition, the toxic nature of the molluscicides to other aquatic macro and microorganisms gave rise to ecological concerns.

In the 1960s, the major antischistosomal drugs were antimonials. Various clinical trials were conducted in the country to evaluate their efficacy [153-159]. The main antischistosomes were lucanthone hydrochloride, sodium antimony Dimercaptosuccinate (TWSb) and ambilhar (a nitrothiazole derivative, 1-(5-nitro-2-thiazolyl)-2-imidazole) [153-157]. The parasitological cure rates of the antimonials varied widely. For instance, TWSb for treatment of S. haematobium had $90 \%$ cure rates among individuals with light infections but in individuals with heavy infection intensity, the cure rate was below 40\% [153-155]. In addition to low cure rates, the antimonials were highly toxic, involved prolonged courses of treatment and had very severe side effects such as epileptiform seizures, psychoses, giddiness and epistaxis [153-157]. Thus, most of these drugs were not recommended for community mass treatment.

The current global strategy of schistosomiasis control is to reduce morbidity by decreasing worm burden and intensity of infection. The strategies aim to improve children's health and prevent irreversible complications in adulthood. This has become possible by the use of praziquantel, and the national control programme uses it [160]. In 1986, a control programme for urogenital schistosomiasis was initiated on the island of Pemba (Pemba Schistosomiasis Control Programme, 19861990) [23-27]. In 2003 the new Schistosomiasis Control Programme ("Kick out Kichocho") was launched in Unguja. The two programs targeted school children and offered praziquantel treatment. The report of Schistosomiasis Control Initiatives indicates that for the period of three years (2004-2006), Zanzibar had successfully completed a countrywide coverage treatment of all school children, using praziquantel (www.sci-ntds.org). At present, SCORE is supporting an ambitious operation research in Pemba and Unguja aiming at (i) eliminating schistosomiasis in Unguja in the coming three years and interrupting transmission in the next five years (ii) to control schistosomiasis in Pemba (prevalence $<10 \%$ ) in the next three years and to eliminate the disease in the 
next five years. The project was implemented in 2011 under the within the context of ongoing national control and prevention efforts. Zanzibar Elimination of Schistosomiasis Transmission (ZEST) is working to achieve these common goals and their results are highly waited. A recent report from Unguja have indicated that the prevalence of $S$. haematobium and other helminth infections have markedly declined on the island for the past 20-25 years and this was attributed to the morbidity control programmes [161]. These findings are encouraging and call for the need of integrating control approach to meet the objectives of the SCORE project.

In 2004, the National Schistosomiasis and Soiltransmitted Helminths Control Programme (NSSCP) under the Ministry of Health and Social Welfare was established with support from the Schistosomiasis Control Initiative (SCI) on the mainland part of Tanzania $[162,163]$. According to an NSSCP report, the schoolbased Mass Deworming Treatment (MDA) has covered 21 regions and each region has received one, two or three rounds of treatment [162].

In the country, various approaches have been used for delivering treatment to endemic communities. The main approach is the school-based MDA, where all primary school children receive praziquantel (40 mg/kgBWT) irrespective of infection status (blanket mass treatment) [162]. In this approach, school teachers administer treatment to the school age children in their respective schools. The school-based deworming programme is advocated as a highly cost effective public health intervention [162]. The other approach is the communitydirected treatment (ComDT) approach, where communities are empowered to decide their own methods of distributing drugs, at their convenient time and ideal places of delivery $[111,164]$. In reported cases, the communities selected people whom they believe would be able to distribute drugs to the children after training [164]. The ComDT approach was at least as effective as the school-based approach in reducing prevalence and intensity of schistosomiasis among school children [164].

Public health education focusing on behavioral change, treatment-seeking and sanitation forms an important part of control programmes for schistosomiasis, especially in rural villages. Knowledge of local perceptions and practices are important in designing and implementation of any of the schistosomiasis control approaches [165]. At community level, qualitative and quantitative studies have reported a fairly good knowledge of symptoms and health-seeking behaviour for schistosomiasis $[165,166]$. On the other hand, poor knowledge on the causes of schistosomiasis was observed [165,166]. Various methods of health education have been tried and practiced in risk groups such as school children, for instance, in Unguja, to increase awareness and knowledge of the school children about schistosomiasis. A booklet titled "Juma na kichocho" (Juma and schistosomiasis) was developed as a teaching aid [167]. However, the information from the booklet did not provide significant changes in knowledge and attitudes of the school children [167]. This was similar to other observations around the Lake Victoria area, where the posters about schistosomiasis provided in primary schools as a source of information did not influence the children's knowledge about the disease [166].

\section{Future control of schistosomiasis: Integrated control approach}

Considering the wide distribution of schistosomiasis in the country and the wide media of transmission, an integrated and sustainable approach is required to control the disease and its associated morbidities. A combination of approaches could be used in human hosts and the intermediate hosts.

For human hosts, repeated mass chemotherapy using praziquantel, public health education focusing on behaviour changes towards risk factors, improve sanitation/hygiene-constructions and use of toilets and supplying tap water in risk groups such as fishing and farming communities, changes of agriculture practices - cultivation in flooded paddy fields and sugarcane plantations and use of gumboots are important measures.

For the intermediate hosts, taking into consideration the seasonal fluctuation of population density of intermediates hosts, timed and selective mollusciciding before aestivation begins, and treatment of snail's habitats at the beginning of the rainy seasons would help to control the disease in small scale [16]. Furthermore, biological control- use of insects or fish, which will feed on snails, or use of competitor snails, is another option for small scale control [72,73].

Recently, integrated control approaches, which used praziquantel treatment along with environmental improvement, water and sanitation, snail control and public health education activities have been reported to be highly effective, and the prevalence of schistosomiasis japonicum infection in human declined to $<1 \%$ in China and in regions of Indonesia (from $4.66 \%$ and $4.8 \%$ to $0.89 \%$ and $0.3 \%$ respectively) $[160,168]$.

The WHO, through its fifty-fourth World Health Assembly resolution, has endorsed chemotherapy with praziquantel as a public health strategy to control schistosomiasis related morbidities [160]. In addition, the resolution has recognized the importance of other public health measures such as the use of safe tape water, improving sanitation and public health education as means to control schistosomiasis [160]. 


\section{Conclusions}

In general, Tanzania has made collective steps to understand the transmission dynamics and control efforts of schistosomiasis over the past seven decades. The evidence revealed here indicates that despite considerable efforts made to control schistosomiasis using various approaches in Tanzania, the disease remains a serious public health problem and its prevalence continues to increase with increase in the population size.

Currently, to respond to the sixty-fifth World Health Assembly resolution, which called for endemic countries and the international community to allocate resources for intensification of schistosomaisis control activities [160], there are new efforts to control schistosomiasis in Tanzania. The funding provided by the Bill and Melinda Gates Foundation and to the Schistosomiasis Initiatives Control (SCI), and the commitment of the Tanzanian government through the Ministry of Health and Social Welfare, has enabled millions of Tanzanian school children to receive at least one to three rounds of praziquantel treatment [162]. In addition, the call of the central government of Tanzania to local district authorities to allocate budget for controlling schistosomiasis, especially for buying and distributing drugs (praziquantel) to risk groups (primary school children) are encouraging measures [169]. However, a single approach of preventive chemotherapy using praziquantel alone cannot overcome the problem of schistosomiasis in Tanzania. There is a need for integrated control programs, acting beyond preventive chemotherapy [160]. In fact, there is a need for deliberate efforts to enforce health education, and more action is needed in improving access and supply of clean tap water and adequate sanitation (especially the use of toilets) [160].

For preventive chemotherapy, there is a need to expand treatment programs to other risk groups such as fishermen, farmers and non-school going children. Furthermore, with the expansion of praziquantel distribution under SCI support (from 2004-2007, about 36.75 million praziquantel tablets were received in Tanzania), there is a need to understand the best approach to distribute the drugs to communities living in various endemic levels of schistosomaisis. Another SCORE funded project is also going on around the Lake Victoria aiming at understand the best approach to distribute anthelminthic to communities with different endemicity level. We hope that the two control projects will yield fruitful results for the future control of the disease.

Lastly, in view of the fact that schistosomiasis occurs in rural areas where the majority of the population are highly stricken by poverty, improvement of the life standard of these communities should go hand in hand with schistosomaisis control activities.

\section{Competing interests}

HDM is supported by the Training Health Researchers into Vocational Excellence in East Africa(THRiVE) Programme funded by Wellcome Trust, grant number 087540 . The authors declare no conflicts of interest.

\section{Authors' contributions}

HDM designed the review, conducted the literature search and drafted the first version of the manuscript. All authors read and approved the manuscript and contributed to its content.

\section{Acknowledgements}

We thank librarians at the NIMR Mwanza centre for assisting in the literature search. Dr. Eliningaya J. Kweka of Tropical Pesticide Research Institute, Arusha, Tanzania for assisting in the literature search.

\section{Author details}

'Department of Medical Parasitology and Entomology, School of Medicine, Catholic University of Health and Allied Sciences, P.O. Box 1464, Mwanza, Tanzania. ${ }^{2}$ Department of Environmental Health and Communicable Disease Control, School of Public Health|, College of Health Sciences, Makerere University, P.O. Box 7072, Kampala, Uganda. ${ }^{3}$ National Institute for Medical Research, Mwanza Research Centre, P.O. Box 1462, Mwanza, Tanzania. ${ }^{4}$ Department of Pathology, Parasitology Section, Cambridge University, Tennis Court Road, Cambridge CB2 1QP, UK. ${ }^{5}$ Department of Community Health, School of Medicine, Federal University of Ceará, Ceará, Fortaleza, Brazil.

Received: 18 September 2012 Accepted: 16 November 2012 Published: 28 November 2012

\section{References}

1. Ross AGP, Bartley PB, Sleigh AC, Olds R, Li Y, Williams GM, McManus DP: Schistosomiasis. New Eng J Med 2002, 346(16):1212-1220.

2. Steinmann P, Keiser J, Bos R, Tanner M, Utzinger J: Schistosomiasis and water resources development: systematic review, meta-analysis, and estimates of people at risk. Lancet Infect Dis 2006, 6(7):411-425.

3. Doumenge JP, Mott KE, Reud-Thomas G: Atlas of the Global distribution of schistosomiasis: Talence, CEGET-CNRS. Geneva: WHO Publication; 1987:233-241.

4. Malenganisho WLM: he role of HIV, micronutrient status and treatment in Schistosoma mansoni infection and morbidity: a cohort study among adult of Ukerewe and Mwanza districts, Tanzania, PhD thesis, Faculty of Science, University of Copenhagen and DBL- Institute for Health Research and Development.; 2005.

5. Cook JH: Distribution of Bilhaziasis on the Victoria Nyanza. Br Med J 1909, 1:1356.

6. Aders WM: Schistosomiasis prevalence and malacological survey in Zanzibar and Pemba Islands. In Annual Report on the medical, sanitary and Biological Division for Zanzibar Protectorate: British Empire; 1928.

7. Blair DM: Bilharziasis survey in British West and East Africa, Nyasaland and the Rhodesias. Bulletin WHO 1956, 15:226-254.

8. Mwambungu JA: Transmission of Schistosoma bovis in Mkulwe (Mbozi district, Mbeya region, Southern highlands of Tanzania. J Helminthol 1988, 62(1):29-32

9. Kinoti G: Observations on the transmission of Schistosoma haematobium and Schistosoma bovis in the Lake Region of Tanganyika. Bull WHO 1964, 31:815-823.

10. Maclean $G$, Webbe G, Msangi AS: A report on a bilharzia and molluscan survey in the Tanga district of Tanganyika. East Afr Med J 1958, 35(1):7-22.

11. Webbe G: A bilharzia and molluscan survey in the Handeni and Korogwe Districts of Tanganyika. J Trop Med Hyg 1959, 62(2):37-42.

12. Sturrock RF: The development of irrigation and its influence on the transmission of bilharziasis in Tanganyika. Bull WHO 1965, 32:225-236.

13. Magendantz M: The biology of Biomphalaria choanomphala and $B$. sudanica in relation to their role in the transmission of Schistosoma mansoni in Lake Victoria at Mwanza, Tanzania. Bull WHO 1972, 47:331-342.

14. Jordan P: Schistosoma haematobium infection in a Sukuma Village, Tanganyika. Bulletin WHO 1961, 25:695-699.

15. Webbe G: The transmission of Schistosoma haematobium in an area of Lake Provience, Tanganyika. Bull WHO 1962, 27:59-85. 
16. Webbe G: Known transmission patterns of S. haematobium in Tanganyika and the possible influence of irrigation on incidence of infection. East Afr Med J 1963, 40:235-239.

17. Waydell SH: Some abdominal complications of S. mansoni as seen on Ukerewe. East Afr Med J 1958, 35:413.

18. Rugemalila JB: The long term consequences of urinary schistosomal infection: changes in a community ten years after a baseline study, PhD thesis, Ross institute, London School of Tropical Medicine and Hygiene.; 1981.

19. McCullough FS: The distribution of Schistosoma mansoni and S. haematobium in East Africa. Tropical Geog Med 1972, 24:199-207.

20. Petrie J: Bihlharzia haematobia. The Lancet 1903, 2:133-134.

21. Goatly KD, Jordan P: Schistosomiasis in Zanzibar and Pemba. East Afr Med J 1945, 42(1):1-9.

22. McCullough FS, Krafft JG: Schistosomiasis in Zanzibar and Pemba. Report on a mission 1 April- 7 June 1975. Geneva: World Health Organization AFR/ SCHIST/34; 1976

23. Savioli L, Mott KE: Urinary schistosomiasis on Pemba Island: Low cost diagnosis for control in a primary health care setting. Parasitol Today 1989, 5(10):333-337.

24. Savioli L, Dixon H, Kisumku UM, Mott KE: Control of morbidity due to Schistosoma haematobium on Pemba Island. Programme organization and management. Trop Geog Med Parasitol 1989, 40:189-194.

25. Savioli S, Hatz C, Dixon H, Kisumku UM, Mott KE: Control of morbidity due to Schistosoma haematobium on Pemba Island: Egg excretion and haematuria as indicators of infection. Amer J Trop Med Hyg 1990, 43(3):289-295.

26. Savioli L, Dixon H, Kisumku UM, Mott KE: Control of morbidity due to Schistosoma haematobium on Pemba Island: selective population chemotherapy of schoolchildren with haematuria to identify high-risk localities. Trans R Soc Trop Med Hyg 1989, 83:805-810.

27. Lwambo NJS, Savioli L, Kisumku UM, Alawi KS, Bundy DAP: Control of Schistosoma haematobium morbidity on Pemba Island: validity and efficiency of indirect screening tests. Bull WHO 1997, 75(3):247-252.

28. Stothard JR, French MD, Khamis IS, Basanez MG, Rollinson D: The epidemiology and control of urinary schistosomiasis and soil-transmitted helminthiasis in schoolchildren on Unguja island, Zanzibar. Trans R SoC Trop Med Hyg 2009, 103:1031-1044

29. Matovu DB, Nditi HP: The distribution and intensity of schistosomiasis in Tanzania mainland. In Proceedings of the Annual Scientific Conference of the Medical Association of Tanzania, Dar Es Salaam.; 1980:12.

30. Matovu DB: Prospects of schistosomiasis at the Kidatu dam project in Tanzania. Trop Geog Med 1977, 30:193-197.

31. Matovu DB: Prospects of schistosomiasis in the proposed Mtera in Tanzania. Trop Geog Med 1978, 30:193-197.

32. Molleman G: A schistosomiasis survey in Mwambani and five other village of Chunya district, Tanzania, Medical Thesis. the Netherlands: University of Nijmegen; 1979:1-74.

33. Foster R: Schistosomiasis on an irrigated estate in East Africa. 1. Background. J Trop Med Hyg 1967, 70:136.

34. Foster R: Schistosomiasis on an irrigated estate in East Africa. 2. Epidemiology. J Trop Med Hyg 1967, 71:159-168.

35. McCullough FS, Eyakuze VM, Msinde J, Nditi H: Water resources and bilharziasis transmission in the Misungwi area, Mwanza district, northwest Tanzania. East Afr Med J 1966, 45(5):295-308.

36. Matovu DB, Nditi HP: Population affected or at risk of schistosomiasis, Proceedings of Medical Association of Tanzania, Annual Conference, September.; 1980:21-26.

37. Chitsulo L, Engels D, Montresor A, Savioli L: The global status of schistosomiasis and its control. Acta Trop 2000, 77:41-51.

38. Jordan P, Webbe G, Sturrock R: Human schistosomiasis. Wallingford, England: CAB; 1993

39. Brooker S, Kabatereine NB, Smith JL, Mupfasoni D, Mwanje MT, Ndayishimiye O, Lwambo NJS, Mbotha D, Karanja P, Mwandawiro C, Muchiri E, Clements ACA, Bundy DAP, Snow RW: An updated atlas of human helminth infections: the example of East Africa. Intern J Health Geogr 2009, 8:42.

40. Brooker S, Hay SI, Issae W, Hall A, Kihamia CM, Lwambo NJS, Wint W, Rogers DJ, Bundy DAP: Predicting the distribution of urinary schistosomiasis in Tanzania using satellite sensor data. Tropical Med Intern Health 2001, 6(12):998-1007.
41. Brooker S, Clements ACA: Spatial heterogeneity of parasite co-infection: Determinants and geostatistical prediction at regional scales. Int J Parasitol 2009, 39(5):591-597.

42. Brooker S, Kabatereine NB, Gyapong JO, Stothard JR, Utzinger J: Rapid mapping of schistosomiasis and other neglected tropical diseases in the context of integrated control programmes in Africa. Parasitol 2009, 136(13):1707-1718

43. Clements ACA, Lwambo NJS, Blair L, Nyandindi U, Kaatano G, Kinung' HI, Webster JP, Fenwick A, Brooker S: Bayesian spatial analysis and disease mapping: tools to enhance planning and implementation of a schistosomiasis control programme in Tanzania. Tropical Med Intern Health 2006, 11(4):490-503.

44. Clements ACA, Deville MA, Ndayishimiye O, Brooker S, Fenwick A: Spatial co-distribution of neglected tropical diseases in the East African Great Lakes region: revisiting the justification for integrated control. Tropical Med Intern Health 2010, 15(2):198-207.

45. Sturrock RF: The Influence of temperature on the biology of Biomphalaria pfeifferi (Krauss), an intermediate host of Schistosoma mansoni. Ann Trop Med Parasitol 1966, 60:100-105

46. Mandahl-Barth G: Intermediate hosts of Schistosoma in Africa. Some recent information. Bullet WHO 1960, 22:565-573.

47. Hotez PJ, Kamath A: Neglected Tropical Diseases in Sub-Saharan Africa: Review of Their Prevalence, Distribution, and Disease Burden. PLoS Negl Trop Dis 2009, 3(8):e412.

48. Rollinson D, Knopp S, Levitz A, Stothard JR, Tchuen Tchuente LA, Garba A, Mohammed KA, Schur N, Person B, Colley DG, Utzinger J: Time to set the agenda for schistosomiasis elimination. Acta Trop 2012. doi:dx.doi.org/10.1016/j.actatropica.2012.04.013

49. McCarthy DD: Medical notes from Wete, Pemba. Trans $R$ Soc Tropic Med Hyg 1930, 23:401-412.

50. Mozley A: Fresh-water Mollusca of the Tanganyika territory and Zanzibar Protectorate and their relation to human schistosomiasis. Trans $R$ SoC Edinburgh 1938, 59:687-744.

51. Brown D: Snails and schistosomes. In Freshwater snails of Africa and their medical importance, 1980, 249-73. London: Taylor and Francis LTD; 1980.

52. Webbe $G$, Jordan P: Recent advances in knowledge of schistosomiasis in East Africa. Trans R Soc Trop Med Hyg 1966, 60(2):279-305.

53. Stothard JR, Rollinson D: Molecular characterization of Bulinus globosus and $B$. nasutus on Zanzibar, and an investigation of their roles in the epidemiology of Schistosoma haematobium. Trans $R$ Soc Tropic Med Hyg 1997, 91:353-357.

54. Lwambo NJS: Transmission of urinary schistosomiasis in Sukumaland, Tanzania. 1. Snail infection rates and incidence of infection in school children. J Helminthol 1988, 62:213-217.

55. Mandahl-Barth G: The species of Bulinus, intermediate hosts of Schistosoma. Bull WHO 1965, 33:33-44.

56. Stothard JR, Mgeni AF, Khamis S, Ameri H, Ramsan M, Savioli L, Loxton N, Rollinson D: The transmission status of Bulinus on Unguja with implications for control of urinary schistosomiasis. Annals Trop Med Parasitol 2000, 94:87-94.

57. Jelnes JE, Thiongo FW, Lwambo NSJ, Ouma JH: The Bulinus nasutus complex (Bulinus nasutus (Martens, 1879) and Bulinus productus Mandahl-Barth, 1960) (Gastropoda: Planorbidae) in the Lake Victoria area elucidated by enzyme-profile electrophoresis and natural infections with Schistosoma spp. (Trematoda: Schistosomatidae).

Steenstrupia, 27(2):257-262. Copenhagen, Denmark, May 2003 (for 2001). ISSN 0375-2909.

58. Stothard JR, Mgeni AF, Khamis S, Seto E, Ramsan M, Hubbard SJ, Kristensen TK: Royal Society of Tropical Medicine and Hygiene. Meeting at Manson House, London, 21 February 2002. Fresh from the field. New insights into the transmission biology of urinary schistosomiasis in Zanzibar. Trans RSocTrop Med Hyg 2002, 96:470-475.

59. Rudge JW, Stothard JR, Basanez MG, Mgeni AF, Khamis IS, Khamis AN, Rollinson D: Micro-epidemiology of urinary schistosomiasis in Zanzibar: Local risk factors associated with distribution of infections among schoolchildren and relevance for control. Acta Trop 2008, 105:45-54.

60. Utzinger J, Tanner M: Microhabitat preferences of Biomphalaria pfeifferi and Lymnaea natalensis in a natural and a man-made habitat in Southern eastern Tanzania. Memorial Instit Oswaldo Cruz, Rio de Janeiro 2000, 95(3):287-294. 
61. Webbe G, Msangi AS: Observations on three species of Bulinus on the east coast of Africa. Annals Tropic Med Parasitol 1958, 52:302-312.

62. Zumstein A: A study of some factors influencing the epidemiology of urinary schistosomiasis at Ifakara (Kilombero District, Morogoro Region. Tanzania. Acta Trop 1983, 40:187-204.

63. Fenwick A, Lidgate HJ: Attempts to eradicate snails from impounded water by the use of N-tritylmorpholine. Bull WHO 1970, 42(4):581-588.

64. Suter R, Tanner M, Borel C, Hostettmann K, Frewogel TA: Laboratory and field trials at Ifakara (Kilombero District, Tanzania) on the plant molluscicide Swartzia madagascariensis. Acta Trop 1986, 43(1):69-83.

65. Jordan P, Webbe G: Epidemiology. In Schistosomiasis, Epidemiology, treatment and Control. London: Heinemann Medical Books; 1982:227-229.

66. Stothard JR, Ameri H, Khamis IS, Blair L, Nyandindi US, Kane RA, Johnston DA, Webster BL, Rollinson D: Parasitological and malacological surveys reveal urogenital schistosomiasis on Mafia Island, Tanzania to be an imported infection. Acta Trop 2012, S0001-706X(12):00311-00317. doi:10.1016/j.actatropica.2012.09.006

67. Marti HP, Tanner HP, DegreÂmont AA, Freyvogel TA: Studies on the ecology of Bulinus globosus, the intermediate host of Schistosoma haematobium, the Ifakara area. Tanzania. Acta Trop 1985, 42:171-187.

68. Gabone RM, Lwambo NJS, Rugemalila JB: Prevalence and intensity of schistosomiasis in Kahangara ward of Magu district and their relationship to the Lake Victoria shore, Paper presented to the 8th Annual joint Scientific Conference of the National Institute for Medical Research, Arusha 22-24 February 1989.30-31.

69. Mutani A, Christensen NO, Frandsen F: Studies on the relationship between Schistosoma and their intermediate hosts. V. The genus Bulinus and Schistosoma bovis from Iringa, Tanzania. Z Parasitenkd 1983, 69(4):483-487.

70. Crossland NO: A large-scale experiment in the control of aquatic snails by the use of molluscicides on a sugar estate in the northern region of Tanganyika. Bull WHO 1963, 29:515-524.

71. Webbe G: Control of transmission of Schistosoma mansoni (sambon) in the Mirongo River. East Afr Med J 1964, 41:508-520.

72. Madsen H: Distribution of Helisoma duryi, an introduced competitor of intermediate hosts of schistosomiasis, in an irrigation scheme in northern Tanzania. Acta Trop 1983, 40(3):297-306.

73. Nguma JF, McCullough FS, Masha E: Elimination of Biomphalaria pfeifferi, Bulinus tropicus and Lymnaea natalensis by the ampullarid snail, Marisa cornuarietis, in a man-made dam in northern Tanzania. Acta Trop 1982, 39(1):85-90

74. Sturrock RF: The Effect of Sublethal Doses of a Molluscicide (Bayluscide) on the Development of Schistosoma mansoni in Biomphalaria sudanicatanganyicensis. Bull WHO 1966, 34:277-283.

75. Kloos H, Fulford AJC, Butterworth AE, Sturrock RF, Ouma JH, Kariuki HC, Thiongo FW, Dalton PR, Klumpp RK: Spatial patterns of human water contact and Schistosoma mansoni transmission and infection in four rural areas in Machakos District, Kenya. Social Sc Med 1997, 44(7):949-968.

76. Bethony J, Williams JT, Brooker S, Gazzinelli A, Gazzinelli MF, LoVerde PT, Correa-Oliveira R, Kloos H: Exposure to Schistosoma mansoni infection in a rural area in Brazil. Part III: household aggregation of water-contact behaviour. Tropical Med Intern Health 2004, 9(3):381-389.

77. Gazzinelli A, Bethony J, Fraga LA, LoVerder PT, Correa-Oliveira R, Kloos H: Exposure to Schistosoma mansoni infection in a rural area of Brazil. I: water contact. Trop Med Intern Health 2001, 6(2):126-135.

78. Gazzinelli A, Velasquez-Melendez G, Crawford SB, LoVerde PT, CorreaOliveira R, Kloos H: Socioeconomic determinants of schistosomiasis in a poor rural area in Brazil. Acta Trop 2006, 99(2-3):260-271.

79. Fenwick A: Baboons as reservoir hosts of Schistosoma mansoni. Trans RSoc Trop Med Hyg 1969, 63:557-567.

80. Muller-Graf CD, Collins DA, Woolhouse ME: Intestinal parasite burden in five troops of olive baboons (Papio cynocephalus anubis) in Gombe Stream National Park, Tanzania. Parasitol 1996, 112(5):489-497.

81. Muller-Graf CDM, Collins DA, Packer C, Woolhouse MEJ: Schistosoma mansoni infection in a natural population of olive baboons (Papio cynocephalus anubis) in Gombe stream National Park. Tanzania. Parasitol 1997, 115:621-627.

82. McMahon JE: A study of some clinico-pathological manifestations in Schistosoma mansoni infections in Tanzania. Annals Trop Med Parasitol 1967, 61(3):302-309.
83. Kardorff R, Gabone RM, Mugashe C, Obiga D, Ramarokoto CE, Mahlert C, Spannbrucker N, Lang A, Gunzler V, Gryseels B, Ehrich JHH, Doehring E: Schistosoma mansoni-related morbidity on Ukerewe Island, Tanzania: clinical, ultrasonographical and biochemical parameters. Trop Med Intern Health 1997, 2(3):230-239.

84. Kardorff R, Mugashe C, Gabone RM, Mahlert C, Doehring E: Diagnostic value of connective tissue metabolites in Schistosoma mansoni related liver disease. Acta Trop, 73:153-164.

85. Fenwick AF, Figenschou BH: The effect of Schistosomamansoni infection on the productivity of cane cutters on a sugar estate in Tanzania. Bull WHO 1972, 47:567-572.

86. Rugemalila JB: The impact of urinary schistosomiasis on the health of two community populations living in endemic areas in Tanzania. TropGeog Med 1979, 31:375-380.

87. Olveda RM, Tiu E, Fevidal P Jr, de Veyra F Jr, Icatio FC Jr, Domingo EO: Relationship of prevalence and intensity of infection to morbidity in schistosomiasis japonica: a study of three communities in Leyte, Phillipines. Am J Trop Med Hyg 1983, 32:1312-1321.

88. Ross AGP, Li YS, Sleigh AC, Li Y, Williams GM, Wu WZ, Lou X, He Y, McManus DP: Epidemiologic features of Schistosoma japonicum among fishermen and other occupational groups in the Dongting Lake region (Human Province) of China. Am J Trop Med Hyg 1997, 57(3):302-308.

89. Warren KS, Domingo EO, Cowan RB: Granuloma formation around schistosome eggs as a manifestation of delayed hypersensitivity. Am J Pathol 1967, 51:735-756.

90. Cheever AW, Hoffmann KF, Wynn TA: Immunopathology of schistosomiasis mansoni in mice and men. Immunol Today 2000, 21:465-466.

91. Vennervald BJ, Dunne DW: Morbidity in schistosomiasis: an update. Current Opin Infect Dis 2004, 17:439-447.

92. Booth M, Vennervald BJ, Kabatereine NB, Kazibwe F, Ouma JH, Kariuki $\mathrm{CH}$, Muchiri E, Kadzo H, Ireri E, Kimani G, Mwatha JK, Dunne DW: Hepatosplenic morbidity in two neighbouring communities in Uganda with high levels of Schistosoma mansoni infection but very different durations of residence. Trans R Soc Trop Med Hyg 2004, 98(2):125-136.

93. Kabatereine NB, Kemijumbi J, Ouma JH, Kariuki HC, Richter J, Kadzo H, Madsen H, Butterworth AE, Ørnbjerg N, Vennervald BJ: Epidemiology and morbidity of Schistosoma mansoni infection in a fishing community along Lake Albert in Uganda. Trans R Soc Trop Med Hyg 2004, 98(12):711-718.

94. Booth M, Vennervald BJ, Kenty L, Butterworth AE, Kariuki HC, Kadzo H, Ireri E, Amaganga C, Kimani G, Mwatha JK, Otedo A, Ouma JH, Muchiri E, Dunne DW: Micro-geographical variation in exposure to Schistosoma mansoni and malaria, and exacerbation of splenomegaly in Kenyan school-aged children. BMC Infects Dis 2004, 4:13.

95. King CH: Disease in schistosomiasis haematobia. In Schistosomiasis. Edited by Mahmoud AAF. London: Imperial College Press; 2001:265-295.

96. Hatz CF, Vennervald BJ, Nkulila T, Vounatsou P, Kombe Y, Mayombana C, Mshinda H, Tanner M: Evolution of Schistosoma haematobium-related pathology over 24 months after treatment with praziquantel among school children in Southern-eastern Tanzania. Am J Trop Med Hyg 1998, 59(5):775-781.

97. Ndyomugyenyi R: Urinary schistosomiasis in schoolchildren in Dar-es-Salaam, Tanzania, and the factors influencing its transmission. Ann Trop Med Parasitol 2001, 95(7):697-706.

98. Zumstein A: A study of some factors influencing the epidemiology of urinary schistosomiasis at Ifakara (Kilombero District, Morogoro Region, Tanzania). Acta Trop 1983, 40:187-204.

99. Sarda RK, Simonsen PE, Mahikwano LF: Urban transmission of urinary schistosomiasis in Dar es Salaam, Tanzania. Acta Trop 1985, 42(1):71-78.

100. Lwambo NJ, Savioli L, Kisumku UM, Alawi KS, Bundy DA: The relationship between prevalence of Schistosoma haematobium infection and different morbidity indicators during the course of a control programme on Pemba Island. Trans R Soc Trop Med Hyg 1997, 91(6):643-646.

101. Mgeni AF, Kisumku UM, McCullough FS, Dixon H, Yoon SS, Mott KE: Metrifonate in the control of urinary schistosomiasis in Zanzibar. Bull WHO 1990, 68(6):721-730.

102. Magnussen P, Ndawi B, Sheshe AK, Byskov J, Mbwana K: Prevalence and morbidity of urinary schistosomiasis among schoolchildren in the Mwera division of Pangani district, Tanzania, 30 months after the last round of 
annual, selective treatments. Ann Trop Med Parasitol 2002, 96(8):843-848.

103. Sarda RK, Minjas JN, Mahikwano LF: Further observations on the use of gross haematuria as an indirect screening technique for the detection of Schistosoma haematobium infection in school children in Dar es Salaam, Tanzania. J Trop Med Hyg 1986, 89(6):309-312.

104. Sousa-Figueiredo JC, Basanez MG, Khamis IS, Garba A, Rollinson D, Stothard JR: Measuring morbidity associated with urinary schistosomiasis: assessing levels of excreted urine albumin and urinary tract pathologies. Plos Negl Trop Dis 2009, 6(3):10:e526.

105. Stothard JR, Sousa-Figueiredo JC, Khamis SI, Garba A, Rollinson D: Urinary schistosomiasis-associated morbidity in schoolchildren detected with urine albumin-to-creatinine ratio (UACR) reagent strips. J Pediatr Urol 2009, 5(4):287-291.

106. Stothard JR, Mgeni AF, Khamis S, Seto E, Ramsan M, Rollinson D: Urinary schistosomiasis in schoolchildren on Zanzibar Island (Unguja), Tanzania: a parasitological survey supplemented with questionnaires. Trans $R$ Soc Trop Med Hyg 2002, 96(5):507-514.

107. Albonico M, Chwaya HM, Montresor A, Stolfzfus RJ, Tielsch JM, Alawi KS, Savioli L: Parasitic infections in Pemba Island school children. East Afri Med J 1997, 74(5):294-298.

108. Rollinson D, Klinger EV, Mgeni AF, Khamis IS, Stothard JR: Urinary schistosomiasis on Zanzibar: application of two novel assays for the detection of excreted albumin and haemoglobin in urine. $J$ Helminthol 2005, 79(3):199-206.

109. Poggensee G, Krantz I, Nordin P, Mtweve S, Ahlberg B, Mosha G, Freudenthal S: A six-year follow-up of schoolchildren for urinary and intestinal schistosomiasis and soil-transmitted helminthiasis in Northern Tanzania. Acta Trop 2005, 93(2):131-140.

110. Lwambo NJ, Siza E, Brooker S, Bundy DA, Guyatt H: Patterns of concurrent hookworm infection and schistosomiasis in schoolchildren in Tanzania. Trans R Soc Trop Med Hyg 1999, 93(5):497-502.

111. Massa K, Magnussen R, Sheshe A, Ntakamulenga R, Ndawi B, Olsen A: The effect of the community-directed treatment approach versus the schoolbased treatment approach on the prevalence and intensity of schistosomiasis and soil-transmitted helminthiasis among schoolchildren in Tanzania. Trans R Soc Trop Med Hyg 2009, 103(1):31-37.

112. Forsyth DM, MacDonald G: Urological complications of endemic schistosomiasis in school-children. Part 1. Usagara school. Trans R Soc Trop Med Hyg 1965, 59(2):171-178.

113. Forsyth DM, Bradley DJ: The consequences of Bilhaziasis. Medical and Public health importance in North-west Tanzania. Bull WHO 1966, 34:715-735.

114. Forsyth DM: A longitudinal study of endemic urinary schistosomiasis in a small East African Community. Bull WHO 1969, 40:771-783.

115. Macdonald G, Forsyth DM: Urological complications of endemic schistosomiasis in schoolchildren. 3. Follow-up studies at Donge School, Zanzibar. Trans R Soc Trop Med Hyg 1968, 62(6):766-774.

116. Lyons B, Stothard R, Rollinson D, Khamis S, Simai KA, Hunter PR: A comparison of urinary tract pathology and morbidity in adult populations from endemic and non-endemic zones for urinary schistosomiasis on Unguja Island, Zanzibar. BMC Infect Dis 2009, 9:189.

117. Kitinya JN, Lauren PA, Eshleman LJ, Paljarvi L, Tanaka K: The incidence of squamous and transitional cell carcinomas of the urinary bladder in northern Tanzania in areas of high and low level of endemic Schistosoma haematobium infection. Trans R Soc Trop Med Hyg 1986, 80(6):935-939.

118. Ajanga A, Lwambo NJS, Blair L, Nyandindi U, Fenwick A, Brooker S: Schistosoma mansoni in pregnancy and associations with anaemia in northwest Tanzania. Trans R Soc Trop Med Hyg 2006, 100:59-63.

119. Malenganisho WL, Magnussen P, Friis H, Siza J, Kaatano G, Temu M, Vennervald BJ: Schistosoma mansoni morbidity among adults in two villages along Lake Victoria shores in Mwanza District, Tanzania. Trans $R$ Soc Trop Med Hyg 2008, 102(6):532-541.

120. Poggensee G, Kiwelu I, Weger V, Goppner D, Diedrich T, Krantz I, Felmeier $\mathrm{H}$ : Female genital schistosomiasis of the lower genital tract: Prevalence and disease-associated morbidity in northern Tanzania. The J Infect Dis 2000, 181:1210-1213.

121. Downs JA, Mguta C, Kaatano GM, Mitchell KB, Bang H, Simplice H, Kalluvya SE, Changalucha JM, Johnson WD Jr, Fitzgerald DW: Urogenital schistosomiasis in women of reproductive age in Tanzania's Lake Victoria region. Am J Trop Med Hyg 2011, 84(3):364-369.

122. El Scheich T, Hofer L, Kaatano G, Foya J, Odhiambo D, Igogote J, Lwambo N, Ekamp H, Karst K, Haussinger D, Richter J: Hepatosplenic morbidity due to Schistosoma mansoni in schoolchildren on Ukerewe Island,Tanzania. Parasitol Res 2012, 110(6):2015-2020.

123. Swai B, Poggensee G, Mtweve $S$, Krantz I: Female genital schistosomiasis as an evidence of a neglected cause for reproductive ill-health: a retrospective histopathological study from Tanzania. BMC Infect Dis 2006, 6:134.

124. Van Raalte JA, Venkataramaiah NR, Shaba JK: Bilharziasis of the female genital tract in Tanzania. East Afr Med J 1981, 58(7):543-547.

125. Moubayed P, Lepere JF, Mwakyoma H, Neuvians D: Carcinoma of the uterine cervix and schistosomiasis. Intern J Gyn Obstetr 1994, 45(2):133-139.

126. Mazigo HD, Zinga M, Heukelbach J, Rambau P: Case series of adenocarcinoma of the prostate associated with Schistosoma haematobium infection in Tanzania. J Global Infects Dis 2010, 2(3):307-309.

127. Feldmeier H, Krantz I, Poggensee G: Female genital schistosomiasis: a neglected risk factor for the transmission of HIV? Trans $R$ Soc Trop Med Hyg 1995, 89:237.

128. Dunne DW, Pearce EJ: Immunology of hepatosplenic schistosomiasis mansoni: a human perspective. Microblnfection 1999, 1:553-560.

129. Gryseels B, Polderman AM: The morbidity of schistosomiasis mansoni in Maniema (Zaire). Trans R Soc Trop Med Hyg 1987, 81:202-209.

130. Vennervald BJ, Kenty L, Butterworth $A E$, Kariuki $C H$, Kadzo $H$, Ireri E, Amaganga C, Kimani G, Mwatha J, Booth M, Ouma JH, Dunne DW: Detailed clinical and ultrasound examination of children and adolescents in a Schistosoma mansoni endemic area in Kenya: hepatosplenic disease in the absence of portal fibrosis. Trop Med Intern Health 2004, 9:461-470.

131. Mazigo HD, Giiti GC, Zinga M, Heukelbach J, Rambau R: Schistosomal peritonitis secondary to perforated appendicitis. Brazil J Infect 2010, 14(6):628-630

132. Stoltzfus RJ, Albanico M, Tielsch JM, Chwaya HM, Savioli L: Linear Growth Retardation in Zanzibarian School Children. J Nutr 1997, 27(6):1099-1105.

133. Stephenson LS, Latham MC, Kurz KM, Kinoti SN, Oduori ML, Crompton DW: Relationships of Schistosoma haematobium, hookworm and malarial infection and Metrifonate treatment to growth of Kenyan school children. Am J Trop Med Hyg 1985, 34:1109-1118.

134. Partnership for Child: Development Heavy schistosomiasis associated with poor short-term memory and slower reaction times in Tanzanian schoolchildren. Trop Med Intern Health 2002, 7(2):104-117.

135. Stephenson LS: Impact of Helminth Infections on Human Nutrition. London, UK: Taylor \& Francis; 1987.

136. Jukes MC, Nokes CA, Alcock KJ, Lambo JK, Kihamia C, Ngorosho N, Mbise A, Yona E, Mwanri L, Baddeley AD, Hall A, Bundy DA, Partnership for Child Development: Heavy schistosomiasis associated with poor short-term memory and slower reaction times in Tanzanian schoolchildren. Trop Med Int Health 2002, 7(2):104-117.

137. Stephenson LS, Latham MC, Kurz KM, Kinoti SN: Single dose Metrifonate or praziquantel treatment in Kenyan children. II. Effects on growth in relation to Schistosoma haematobium and hookworm egg counts. Am J Trop Med Hyg 1989, 41:445-453.

138. Mazigo HD, Waihenya R, Lwambo NJS, Mnyone LL, Mahande AM, Seni J, Zinga M, Kapesa A, Kweka EJ, Mshana SE, Heukelbach J, Mkoji GM: Co-infections with Plasmodium falciparum, Schistosoma mansoni and intestinal helminth among schoolchildren in endemic areas of northwestern Tanzania. BMC Par Vectors 2010, 3:44.

139. Mazigo HD, Lwambo NJS, Mkoji GM, Laurent LM, Kweka EJ, Waihenya R: Anaemia and organomegaly associated with parasitic infections among schoolchildren in Sengerema District, north--western. Tanz J Health Res 2010, 12(2):126-136.

140. Mazigo HD, Kidenya BR, Ambrose EE, Zinga M, Waihenya R: Association of intestinal helminths and $P$. falciparum infections in co-infected school children in northwest Tanzania. Tanz J Health Res 2010, 12(4):283-285.

141. Mboera LE, Senkoro KP, Rumisha SF, Mayala BK, Shayo EH, Mlozi MR: Plasmodium falciparum and helminth coinfections among schoolchildren in relation to agro-ecosystems in Mvomero District, Tanzania. Acta Trop 2011, 120(1-2):95-102. 
142. Lwambo NJS, Brooker S, Siza JE, Bundy DAP, Guyatt H: Age patterns in stunting and anaemia in African school children: a cross sectional study in Tanzania. Europ J Clin Nutr 2000, 54:36-40.

143. Sousa-Figueiredo JC, Basanez MG, Mgeni AF, Khamis IS, Rollinson D, Stothard JR: A parasitological survey, in rural Zanzibar, of pre-school children and their mothers for urinary schistosomiasis, soil-transmitted helminthiases and malaria, with observations on the prevalence of anaemia. Annals Trop Med Parasitol 2008, 102(8):679-692.

144. Tatala SR, Kihamia CM, Kyungu LH, Svanberg U: Risk factors for anaemia in schoolchildren in Tanga region, Tanzania. Tanz J Health Res 2008, 10(4):189-202

145. Brown M, Mawa PA, Kaleebu P, Elliott AM: Helminths and HIV infection: epidemiological observation on immunological hypotheses. Paras/mmunol 2006, 28:613-623.

146. Secor WE: Interactions between schistosomiasis and infection with HIV-1. Paras Immunol 1970, 42:589-596.

147. Berhe N, Myrvang B, Gundersen SG: Intensity of Schistosoma Mansoni, Hepatitis B, Age, and Sex Predict Levels of Hepatic Periportal Thickening/Fibrosis (PPT/F): A Large-Scale Community-Based Study in Ethiopia. Am Trop Med Hyg 2007, 77(6):1079-1086.

148. Crossland NO: Bilhaziasis in Arusha chini. In Tropical Pesticides Research Institute, Annual report. Arusha:; 1962:18.

149. Fenwick A: The Development of Snail Control Methods on an Irrigated Sugar-Cane Estate in Northern Tanzania. Bull WHO 1970, 42:589-596.

150. Crossland NO: A mud-sampling technique for the study of the ecology of aquatic snails and its use in the evaluation of the efficacy of molluscicides in field trials. Bull WHO 1962, 27:125-133.

151. Crossland NO: Field trials to evaluate the effectiveness of the molluscicide N-Tritylmorpholine in irrigation systems. Bull WHO 1967, 37:23-42.

152. Webbe G: Laboratory and field trials of a new molluscicide, Bayer 73, in Tanganyika. Bull WHO 1961, 25:525-531.

153. Jordan P, Randall K: Schistosomiasis in Tanganyika. Observations on suppressive management of S. haematobium with TWSb, with particular reference to reduction in ova load. Trans R Soc Trop Med Hyg 1972, 56(6):523-528

154. Jordan P: Daily and weekly injection of Sodium antimony Dimercaptosuccinate (TWSb) in the treatment of Schistosoma haematobium infection. Bull WHO 1965, 33:553-556.

155. Jordan P: Schistosomiasis in Tanzania. Long term results of TWSb and Lucanthone hydrochloride combined in suppressive therapy in Schistosoma haematobium infection. Trans R Soc Trop Med Hyg 1966, 60(1):83-91.

156. Davis A: Field trials of Ambilhar in the treatment of urinary bilharziasis in schoolchildren. Bull WHO 1966, 35:827-835.

157. Jordan P: Trial of Ambilhar, a Nitrothiazole derivative, in S. mansoni infections in Tanzania. BMJ 1966, 1:276-278.

158. McMahon JE, Kilala CP: Clinical trial with Ambilhar in Schistosoma mansoni infections in Tanzania. Br Med J 1966, 2(5521):1047-1049.

159. Davis $A$ : Comparative trials of antimonials drugs in urinary schistosomiasis. Bull WHO 1968, 38:197-227.

160. World Health Organization: Key issues and challenges arising out of the Sixty-fifth World Health Assembly and the 130th and 131st sessions of the WHO Executive Board. Elimination of schistosomiasis (WHA65.21), Sixty-fifth Session SEA/RC65/17, Yogyakarta, Indonesia5-7. 2012.

161. Knopp S, Stothard RJ, Rollinson D, Mohammed KA, Khamis SI, Marti H, Utzinger J: From morbidity control to transmission control: time to change tactics against helminths on Unguja island, Zanzibar. Acta Trop 2012. doi:10.1016/j.actatropica.2012.04.010.

162. : Report on urinary schistosomiasis, national questionnaire baseline survey in Tanzania mainland 2010: Schistosomiasis Control Initiative. Ministry of Health and Social Welfare Tanzania Mainland 2010,1-98.

163. Fenwick A: New initiatives against Africa's worms. Trans $R$ Soc Trop Med Hyg 2006, 100:200-207.

164. Massa K, Magnussen P, Sheshe A, Ntakamulenga R, Ndawi B, Olsen A: Community perceptions on the community-directed treatment and school-based approaches for the control of schistosomiasis and soiltransmitted helminthiasis among school-age children in Lushoto district, Tanzania. J Biosocia Sci 2009, 41:89-105.

165. Mwanga JR, Magnussen P, Mugashe CL, Gabone RM, Aagaard-Hansen J: Schistosomiasis-related perceptions, attitudes and treatment-seeking practices in Magu district, Tanzania: public health implications. J Biosocia Sci 2004, 36:63-81.

166. Mazigo HD, Waihenya R, Mkoji GM, Zinga M, Ambrose EE, Jahanpour OF, Bahemana E, Mnyone LL, Kweka EJ, Lwambo NJS: Intestinal schistosomiasis: prevalence, knowledge, attitude and practices among school children in an endemic area of north western Tanzania. J Rural Trop Public Health 2010, 9:53-60.

167. Stothard JR, Mook P, Mgeni AF, Khamis IS, Khamis AN, Rollinson D: Control of urinary schistosomiasis on Zanzibar (Unguja Island): a pilot evaluation of the educational impact of the Jumana Kichocho health booklet within primary schools. Memorial Instit Cruz, Rio de Janeiro 2006, 101(suppl 1):119-124.

168. Wang LD, Chen HG, Guo JG, Zeng XJ, Hong XL, Wu XH, Wang XH, Wang LY, Xia G, Hao Y, Chin DP, Zhou XN: A strategy to control transmission of Schistosoma japonicum in China. New Eng J Med 2009, 360(2):121-128.

169. Kabatereine NB, Fleming FM, Nyandindi U, Mwanza JCL, Blair L: The control of schistosomiasis and soil transmitted helminths in East Africa. Trends Parasitol 2006, 22(7):332-339.

doi:10.1186/1756-3305-5-274

Cite this article as: Mazigo et al:: Epidemiology and control of human schistosomiasis in Tanzania. Parasites \& Vectors 2012 5:274.

\section{Submit your next manuscript to BioMed Central and take full advantage of:}

- Convenient online submission

- Thorough peer review

- No space constraints or color figure charges

- Immediate publication on acceptance

- Inclusion in PubMed, CAS, Scopus and Google Scholar

- Research which is freely available for redistribution

Submit your manuscript at www.biomedcentral.com/submit
C) Biomed Central 